ANADOLU, J. of AARI ISSN: 1300-0225 (Print) E-ISSN: 2667-6087 (Online) 2020, 30 (2): 129-152

DOI: $10.18615 /$ anadolu. 834820

\title{
Türkiye Yağlık Ayçiçeği (Helianthus annuus L.) Genetik Kaynaklarının Karakterizasyonu
}

\author{
Ayşegül ALTUNOK MEMiş̧ ${ }^{1 *}$ (D) Muzaffer TOSUN ${ }^{2}$ \\ ${ }^{1}$ Ege Tarımsal Araştırma Enstitüsü Müdürlüğü, Menemen-İzmir/TURKEY \\ ${ }^{2}$ Ege Üniversitesi, Ziraat Fakültesi Tarla Bitkileri Anabilim Dal, Bornova-İzmir/TURKEY \\ ${ }^{1}$ https://orcid.org/0000-0003-3419-3202 $\quad{ }^{2}$ https://orcid.org/0000-0001-7989-4737 \\ *Corresponding author (Sorumlu yazar): aysegul.altunok@tarimorman.gov.tr \\ Received (Geliş tarihi): 09.06.2020Ａccepted (Kabul tarihi): 14.07.2020
}

ÖZ: Ayçiçeği (Helianthus annuus L.) dünyada ve ülkemizde tohumlarından elde edilen bitkisel yă̆ için üretilmektedir. Yüksek yağ oranı (\% 45-50) ve kalitesiyle dünyada ve ülkemizde ekonomik olarak önemli bir yăg bitkisidir. Orjini Kuzey Amerika olan ayçiçeği, yerel çeşit olarak da Türkiye'de geniş çeşitliliğe sahiptir. Türkiye'nin farklı ekolojik bölgelerinde yağlık ve çerezlik olarak farklı yerel çeşitler yetiștirilmektedir. Ege Tarımsal Araștırma Enstitüsü (ETAE) bünyesinde bulunan Ulusal Gen Bankası (Menemen-İzmir)'nda uzun süreli olarak muhafaza edilen ayçiçeği genetik kaynakları bu projenin materyalini olușturmuștur. Projede; UPOV ve IBPGRI tanımlama listelerinde belirlenen karakterler üzerinden morfolojik, fenolojik ve teknolojik olarak toplam 43 karakter açısından gözlem ve ölçümler alınmıştır. Augmented Deneme Deseninde elde edilen veriler Ana Bileşen Analizi (ABA) ve Kümeleme Analizi (KÜME) ile değerlendirmişstir. Kantitatif karakterlerden olan \% 50 çiçeklenme gün sayısı, fizyolojik olum gün sayısı, bitki boyu (cm), gövde alt çapı (mm), gövde üst çapı (mm), yaprak eni (cm), yaprak boyu $(\mathrm{cm})$, tabla çapı $(\mathrm{cm})$, tane eni $(\mathrm{mm})$, tane boyu $(\mathrm{mm})$, tek bitki verimi $(\mathrm{g} / \mathrm{tabla})$, yă oranı $(\%)$ ve 1000 tane ağırlığ (g) bakımından örneklerde büyük oranda varyasyonlar tespit edilmiştir. Kalitatif karakterler bakımından; tane şekli, tabla şekli, üniformite, bitki gelişimi ve bitki dallanması karakterlerinde yüksek varyasyon görülmüştür. Sonuç olarak; yağlık ayçiçeği olarak şekillenen ıslahçı hedefleri doğrultusunda değerlendirilen bu karakterlere göre yapılan tanımlamaların, ileride yapılacak ıslah çalıșmalarında hedefe uygun materyal seçimi noktasında ıslahçılara büyük kolaylık sağlayacă̆ı düşünülmektedir. Ayrıca üretim ve yenileme kapsamında çoğaltılan gen kaynă̆ı materyalinin Ulusal Gen Bankası'nda uzun süreli olarak muhafaza edilecek olması da çalışmadan elde edilen bir diğer sonuçtur.

Anahtar kelimeler: Ayçiçeği, Helianthus annuus L. morfometrik karakterizasyon, ana bileşen analizi, ABA, kümeleme analizi.

\section{Characterization of Oilseed Sunflower (Helianthus annuus L.) Genetic Resources of Turkey}

ABSTRACT: Sunflower (Helianthus annuus L.) is a vegetable oil obtained from seeds produced in our country and in the world. It is an economically important oil plant in the world and in our country with its high oil rate (45-50\%) and quality. Origin of sunflower is North America, there have wide variety of local varieties in Turkey. Different oilseed and confectionary sunflower local varieties are grown in different ecological regions of Turkey. Sunflower genetic resources which the material of this project are kept as long term in National Seed Gene Bank at Aegean Agricultural Research Institute (AARI) in Menemen, Izmir. In the project; morphological, phenological and technological observations and measurements were taken for 43 characters in total, over the characters specified in the UPOV and IBPGRI definition lists. The data obtained from Augmented Experimental Design were evaluated by Principal Component Analysis (PCA) and Cluster Analysis. Quantitative characters of days to $50 \%$ flowering, days to physiological maturity, plant height ( $\mathrm{cm})$, stem lower part diameter (mm), stem upper part diameter $(\mathrm{mm})$, leaf width $(\mathrm{cm})$, leaf length $(\mathrm{cm})$, head diameter $(\mathrm{cm})$, seed width $(\mathrm{mm})$, seed length $(\mathrm{mm})$, single plant yield $(\mathrm{g} / \mathrm{tabla})$, oil percentage $(\%)$ and 1000 seed weight $(\mathrm{g})$ in terms of large variations in and oil samples have been identified. In 
terms of qualitative characters, high variation was seen in the grain shape, head shape, uniformity, plant growth and plant branching. In terms of qualitative characters, high variation was seen in the grain shape, head shape, uniformity, plant growth and plant branching. As a result; It is thought that the descriptions made according to these characters, which are evaluated in line with the breeder's goals in oil sunflower breeding, will provide great convenience to the breeders in choosing the appropriate material for the future breeding studies. In addition, this study covered multiplication and regeneration work with reproduced confectionary sunflower genetic source material is maintained in the long term in the National Gene Bank.

Keywords: Sunflower, Helianthus annuus L., morphometric characterization, principal component analysis, PCA, cluster analysis.

\section{GíRiş}

Bitkisel yağlar insan beslenmesinde büyük öneme sahiptir. Ayçiçeği (Helianthus annuus L.); yüksek yağ oranı (\% 45-50) ve yağ kalitesiyle endüstri bitkileri içerisinde dünyada ve ülkemizde ekonomik açıdan önemli bir bitkidir. Ayçiçeği (Helianthus annuus L.), Asteraceae (Compositae) familyasından Helianthus türüne ait birçok morfolojik özellikleri yönünden büyük varyasyon gösteren tür zenginliğine sahip bir bitki olup tek yıllık formlarının yanı sıra çok yıllık formları da mevcut bir bitkidir (Miller, 1987).

Orjini Kuzey Amerika olan ayçiçeğinin (Zeven ve de Wet, 1982; Heiser ve ark., 1969; Heiser, 1978; Putt, 1978; Miller, 1987) Kuzey Amerika'dan İspanyollar tarafindan 1510 yılında Avrupa'ya getirildiği bildirilmektedir (Zukovsky, 1950). Yenilebilir yağ kalitesi olarak diğer bitkilerden elde edilen yemeklik yağlardan daha sağlıklı olmasinın (Andrade ve ark., 2011) yanı sira çerezlik olarak tüketimiyle de ele alındığında ayçiçeğinin ekonomik önemi daha iyi anlaşılabilmektedir (Tan ve Tan, 2010; Tan ve ark., 2013a).

2016 y1lı verilerine göre; Türkiye, 3.164 .000 ton yağlı tohum, 1.482.000 ton ham yağ ve 1.584 .000 ton küspe ithal etmiştir. Yağlı tohumlar ve türevleri için yapılan ithalata; yağlı tohum için 1.401.000.000 dolar, ham yağ için 1.590.000.000 dolar ve küspe için 444.000 .000 dolar toplam olarak 3.435.000.000 dolar para ödenmiştir. Ayrıca 889.000 ton bitkisel yağ ihracat1 ile 943.000000 dolarlık gelir elde edilmiştir (Anonim, 2017).

Ülkemiz genelinde 2016 y1lında 1.500 .000 ton yağlık ve 170.716 ton çerezlik ayçiçeği üretimi gerçekleşmiş, bu üretimlerden $250 \mathrm{~kg} / \mathrm{da}$ verim elde edilmiştir. $\mathrm{Bu}$ verim, dünya ortalamasının $(164,4 \mathrm{~kg} / \mathrm{da})$ çok üzerindedir (Anonim, 2017; Anonymous, 2017).
Ancak ülkemiz tüketimi göz önünde tutulduğunda bu miktar yeterli olmamaktadır. İhtiyaçları karşılayabilmek adına üretim alanlarının artırılması, ikinci ürün tarımının teşvik edilmesinin yanı sıra mevcut materyalde verimi artırmak bir diğer çözüm olarak karşımıza çıkmaktadır. Bu amaçla 1slahta belirlenen hedeflere ulaşabilmek (yüksek verim, ikinci ürün tarımına uygunluk, yüksek oleik asit; hastalıklara, zararlılara ve kurağa dayanıklılık vb.) için hazırlanacak islah programlarında başlangıç materyali olarak gen bankasında bulunan örneklere başvurulmaktadır.

Ülkemiz, endüstri bitkilerinin de (Pancar, haşhaş, susam, tütün, crambe, keten, kenevir, aspir, ayçiçeği, yağ şalgamı vb.) içinde yer aldığ 1 birçok bitki türünde mikro gen merkezi konumundadır. Bitki çeşitliliği ve genetik kaynaklar açısından çok önemli bir coğrafyada yer alan Türkiye türler bakımından önemli bir potansiyele ve varyasyona sahip bulunmaktadir (Harlan, 1951; Tan,1992; Tan ve Tan, 1996; Karagöz ve ark., 2010; Tan, 2010; Tan ve Tan, 2010; Tan ve ark., 2014) .

Türkiye ayçiçeğinin gen merkezi olmamasına rağmen yerel çeşitlerdeki agro-morfolojik çeşitliliğin nedenleri; adaptasyon sırasında gerçekleşen doğal seleksiyon ve tüketim amaçlarına yönelik özellikler açısından yapılan çiftçi seleksiyonu ile açıklanabilir (Tan, 2009).

Ülkemiz endüstri bitkilerinin bir kısmının tarımı halen köy çeşitleri olarak yapılmakta iken bir kısmının tarımı ise giderek gerilemektedir. Uygulanan tarım politikalarının sonucu olarak ekim alanlarının daralması, yeni ıslah edilmiş çeşitlerin yerel çeşitlerle ikame etmesi ve geleneksel tarım sistemleri ile üretimin ekonomik olmaması bu yerel çeşitlerin ekiminin giderek azalmasına neden olmaktadır (Tan ve ark., 2014). $\mathrm{Bu}$ uygulamaların sonucunda diğer ürün gruplarında olduğu gibi endüstri bitkilerinde de 
ortaya çıkan genetik tabandaki daralma açıkça görülmektedir. Ayrıca, yabani türlerin çeşitli nedenlerle yok olmasından dolayı bunların yabani kaynakları büyük önem arz etmektedir (Zukovsky, 1950; Zeven ve de Wet, 1982). Harlan ve de Wet (1971) kültür bitkileri ile bunların yabani akrabalarının aynı gen havuzunda olmak kaydıyla kolaylıkla melezlenebileceğini ve elde edilen bu materyallerden 1slahta yararlanılabileceğini bildirmektedirler. Bu bakımdan gerek köy çeşitleri ve gerekse bunların yabani akrabaları 1slah çalışmalarında kullanılmakta olup ülkemiz bu potansiyeli ile endüstri bitkileri açısından da önemli bir yere sahip bulunmaktadır (Tan ve Tan, 2010; Tan ve Tan, 2011; Tan ve Tan, 2012; Tan ark., 2014).

Allard (1970) uygun bir örnekleme prosedürünün, türün genetik varyasyon paterni (coğrafik dağılım gösterdiği alanda), türün lokal populasyon içindeki genetik varyasyonuna ve toplama (koleksiyon) yapıldiktan sonra da genetik varyasyonun devam ettirilmesine bağlı olduğunu bildirmiştir. Koleksiyonlar içindeki bu varyasyonun belirlenmesi için de toplanan materyalin karakterizasyonu büyük önem taşımaktadır.

Upadhyaya ark. (2008), germplazmların 1slahta sinırlı kullanılmalarının nedenlerinden birisinin de genotip x çevre interaksiyonu gösteren ve farkl1 çevrelerde değerlendirilmeyi gerektiren, ekonomik öneme sahip özelliklere ait bilgi eksikliği olduğunu bildirmişlerdir. Araştırmacılar, geniş germplazm koleksiyonlarının farklı çevrelerde değerlendirilmesinin maliyeti oldukça yüksek araştırmalar olmasından dolayı dünyadaki gen bankalarında çekirdek koleksiyon oluşturma yoluna gidilmesi gerektiğini öngörmektedirler.

Islahta kullanılacak olan germplazmların amaca uygun kullanılabilmesi için agronomik ve morfolojik özelliklerin karakterizasyonu gerekmektedir. Nitekim; Roy ve ark. (1999), bitki yapraklarındaki tüylülük arttıkça kurak koşullarda su kaybının azaldığını bildirmektedir. Kuraklık açısından önem arz eden tüylülük karakteri bakımından genetik kaynakları materyalinin karakterizasyonu, yapilacak bilimsel ve islah çalışmaları açısından önem taşımaktadır.
Ege Tarımsal Araştırma Enstitüsünde (ETAE) Endüstri Bitkileri Genetik Kaynakları Projesi kapsamında şimdiye kadar toplam olarak 89 adet ayçiçeği materyali IBPGRI (International Board for Plant Genetic Resources) ve UPOV (The International Union fort he Protection of New Varieties of Plants)'da yer alan karakterlerle gözlemler yapılarak morfometrik karakterizasyonu tamamlanmıştır (Tan ve Tan, 2010; Tan ve Tan, 2012; Tan ve ark., 2013a; Tan ve ark., 2013b).

Cantamutto ve ark. (2010), Arjantin'de yaptıkları çalışmada yabani ayçiçeği populasyonlarından oluşturulan germplazmları, coğrafi açıdan farklı 9 lokasyonda bitki boyu, sap çapı, tabla açısı, yaprak ve tabla sayıs1, yaprak eni ve boyu gibi pek çok morfolojik karakterler açısından gözlemlemişlerdir. Çalışmada ABA analizi ile mevcut materyal; vejetasyon süresi, çiçeklenme, tane ve yă kompozisyon açısından 4 grupta değerlendirilmiş, ek olarak Ward (1963) metoduna dayanan Kümeleme Analizi ile lokasyonlar arasındaki çevresel benzerlikler analiz edilmiştir. Sonuç olarak; Arjantin'deki yabani ayçiçeği populasyonlarındaki yüksek biyoçeşitlilik düşünüldüğünde ayçiçeği 1 slahında kullanılmak üzere yeni germplazmların geliştirilerek yabani formlardan gen akışının sağlanabileceği sonucuna ulaşmışlardır.

Shamshad ve ark. (2014), çalışmalarında 31 adet germplazm kullanmışlardır. Tesadüf Blokları Deneme Deseninde 2 siralı 3 tekerrürlü olarak kurdukları denemede bitki boyu, tabla çapı, 100 tane ağırlığı, tek bitki verimi gibi kriterlerde gözlemler yapmışlardır. Elde ettikleri verileri yeteri kadar genetik çeşitliliği içeren 6 kümede toplayarak kümeler arası ve kümeler içi değerlendirmişlerdir. Sonuç olarak maksimum genetik çeşitliliği gözlemledikleri küme 2 ve küme 4 ile oluşturulacak kombinasyonlardan yüksek verimli hibritler elde edilebileceğini bildirmişlerdir.

Nooryazdan ve ark. (2010), çalışmalarında, ABD'den getirilen 77 adet yabani ayçiçeği örneğini Fransa'da13 adet kantitatif karakter bakımından kümeleme, ana bileşen ve discriminant analizini kapsayan multivaryete metodlarını kullanarak karşılaştırmışlardır. Coğrafi ve iklim verilerinin analizi sonucunda iklim verileri ile morfolojik uygulamalar arasında varyasyon olduğu 
sonucuna ulaşmıșlardır ve iklim verileri bakımından örnekler 4 kümede toplanmışlardır. Tek yıllık ayçiçeği örneklerinin karakteristik özelliklerini özetlemekte kullanılan ABA analizi ile yabani ayçiçeklerinin coğrafi profillerini tanımlamışlardır.

Khoufi ve ark. (2013), çalışmalarında 73 hat ve 7 hibrit kullanarak bunlar arasindaki varyasyonu ve çeşitliliği belirlemek için morfolojik ve fenolojik analizleri birleştirerek değerlendirmişlerdir. Morfolojik karakterizasyon çalışmasında bitki boyu, tabla çap1, tane eni ve boyu, yaprak eni ve boyu, yaprak en/boy oran1, çiçeklenme gün sayıs1, fizyolojik olum gün sayısı, vejetasyon süresi, 100 tane ağırlığı, kabuk/iç oranı gibi kriterler üzerinden yapılan gözlemler istatistiki olarak değerlendirilmiştir. Çalışmada varyans analizi, ABA ve kümeleme analizi farklı hatlar arasında morfolojik ve fenolojik varyasyon olduğunu göstermiştir.

Odong ve ark. (2013), yapmış oldukları çalışmalarında gen bankasındaki bitki genetik kaynaklarının etkin ve verimli kullanılması için germplasm koleksiyonlarının genetik yapısının anlaşılması gerektiğini, çalışmanın bu aşamasında yer alan kümeleme analizinin ve ana bileșen analizinin kullanılmasıyla geliştirilebileceği sonucunu elde etmişlerdir.

Ghariani ve ark. (2003), çok y1llık çimde yaptıkları çalışmada; 16 populasyon ve 2 çeşit kullanılarak 11 adet morfometrik özellikten faydalanarak değerlendirme yapmışlardır. Veriler ABA ile değerlendirilmiş ve 2 ana küme oluşmuştur. İlkinde populasyonların bazıları ve çeşitler birleştirilerek değerlendirilirken ikinci grupta birleştirilen populasyonlar yer almıştır. Sonuç olarak birkaç populasyon ile çeşitlerin büyük benzerlikler gösterdiği bildirilmiştir.

Tan ve Tan (1996), yaptıkları araştırmada Türkiye'nin 28 ilinden toplanan ve ETAE bünyesindeki Ulusal Tohum Gen Bankası'nda muhafazaya alınan 90 adet susam örneği üzerinde yapmış oldukları çalışmada Sesamum indicum L. örneklerinin morfolojik benzerlik ve farklılıkları analiz etmişler, tüylülük ve üzerinde çalışılan 46 karakter bakımından geniş bir varvasyon olduğunu saptamışlardır. Türkiye susam gen kaynakları materyalinin içerdiği varyasyon ve bu materyalin değerlendirilmesi sonucu elde edilen araștırma sonuçları 1slahçı ve agronomistler için önem taşımaktadır (Harlan, 1951; Bedigan, 1981; Tan ve Tan, 1996). Benzer şekilde Demir (1962), susam örnekleri üzerinde yaptığı çalışmada; çiçek, yaprak, tüylülük, kapsül sayısı, bölmeleri ve tohum rengi karakterleri bakımından Türkiye örneklerinin diğer ülke örneklerine oranla daha geniş varyasyon gösterdiği sonucuna ulaşmıştır.

Mevcut çalışmalar 1şı̆̆ında bitki genetik kaynaklarının değerlendirilmesi ve bunun dokümantasyonu, mevcut koleksiyonlardaki genetik varyasyonun ortaya konması açısından önem taşımaktadır (Bennet, 1970; Bunting ve Kuckuck, 1970). Söz konusu genetik materyalin günümüzde ve gelecekte kullanılabilmesi için; kaybının önlenmesi ve korunması gerekmektedir (Tan ve ark., 2013a; Tan ve ark., 2013b; Tan ve ark., 2014).

$\mathrm{Bu}$ çalışmanın ana amac1; Türkiye Ulusal Tohum Gen Bankasında bulunan yağlık ayçiçeği genetik kaynakları materyalinin karakterizasyonunun yapmak, tanımlanan bu materyalin ile de islah çalışmaları ve diğer bilimsel araştırmalar için bir kaynak oluşturmasını sağlamak amaçlanmıştır.

\section{MATERYAL ve METOT}

$\mathrm{Bu}$ çalışmada; ETAE bünyesinde bulunan Ulusal Gen Bankasinda muhafaza edilen Türkiye'nin hemen her bölgesinden toplanmış olan 94 adet yağlık ayçiçeği örneği kullanılmıştır (Çizelge 1). Çalışma 2017-2018 yıllarında ETAE'de gerçekleştirilmiştir.

Ayçiçeğinde yapılan çalışmalarda genetik farklılıkların belirlenmesinde morfometrik karakterlerin kullanımı, materyalin amaca uygun kullanılabilmesi noktasinda yol gösterici olmuştur (Arshad ve ark., 2007).

Araştırma materyali olan 94 yağllk ayçiçeği örneğinde, IPGRI (Anonymous, 1985) ve UPOV (Anonymous, 2000) karakterleri dikkate alınarak belirlenen 43 karakter bakımından gözlemler ve ölçümler yapılmıştır (Çizelge 2).

Tohum miktarı yeterli olan örneklerde karakterizasyon çalışması; tohum rezerv miktarlarının az olduğu belirlenen bazı örnekler için ise de hem karakterizasyon hem de üretim/yenileme çalışmaları yapılmıştır. 
Karakterizasyon yapılan örneklerde tesadüfi olarak seçilen 10 bitkide torbalama işlemi yapılırken üretim/yenileme ile birlikte karakterizasyonu yapılacak örneklerde tüm bitkilerde torbalama işlemi yapılmıştır.

\section{Gözlem ve ölçümler}

Çiçeklenme gün sayısı (gün): Çıkış ile \%50 çiçeklenmenin olduğu R5 (Schneiter ve Miller, 1981) devresinde yapılmıștır.

Fizyolojik olum gün sayısı (gün): Çıkış ile \%50 fizyolojik olumun tamamlandığ 1 R9 (Schneiter ve Miller, 1981) devresinde yapılmıştır.

Bitki boyu (cm): R9 devresinde bitkinin kök boğazı ile sapın tablaya bağlandığı nokta arasındaki mesafenin $\mathrm{cm}$ olarak değeri ölçülmüştür. Bitki boyu her parselde tesadüfi olarak seçilen 10 bitkide yapılan ölçümlerin ortalaması olarak kaydedilmiştir.

Tabla çapı (cm): R9 devresinde her parselde tesadüfi olarak seçilen 10 bitkinin tablası diştan dışa ölçülerek ortalama değer alınmıştır.
Yă̆ oranı (\%): Nukleer Magnetic Rezonans sistemine göre çalışan NMR cihazı ile saptanmıştır (Granlund ve Zimmerman, 1975). Yağ oranı ölçümleri her parselde dört parelel olarak yapılarak ortalaması alınmıştır. Analizler Trakya Tarımsal Araştırma Enstitüsü Müdürlügü̆Teknoloji Laboratuvarında bulunan NMR cihazı kullanılarak yapılmıştır.

Tek bitki verimi (g/tabla): Her parselde tesadüfi olarak seçilen 10 bitkinin tablasından tane olarak elde edilen tohumların ağırlı̆̆ının ortalaması alınarak hesaplanmıştır. Değerlendirmeler \%10 nemde yapılmıştır.

1000 tane ağırlı̆̆ı (g): Her parselden tesadüfi olarak seçilen 10 adet bitki örneği bulk edilmiştir. Bin tane ağırlığ 1 , hazırlanan bu numuneden 4 adet 100 tohum ağırlı̆̆ının ortalamasının 10 ile çarpılması ile hesaplanmıştır. Değerlendirmeler \%10 nemde yapılmıştır.

Çizelge 1. Çalışma materyali yağlık ayçiçeği genetik kaynakları ve toplandığı yöreler.

Table 1. Research material of oilseed sunflower genetic resources and their collection provinces.

\begin{tabular}{|c|c|c|c|c|c|c|c|c|c|c|c|}
\hline No. & $\begin{array}{l}\text { Kayit } \\
\text { No. } \\
\text { Accession } \\
\text { No. } \\
\end{array}$ & $\begin{array}{l}\text { Toplama } \\
\text { yeri } \\
\text { Collection } \\
\text { provinces }\end{array}$ & No. & $\begin{array}{l}\text { Kayit } \\
\text { No. } \\
\text { Accession } \\
\text { No. } \\
\end{array}$ & $\begin{array}{l}\text { Toplama } \\
\text { yeri } \\
\text { Collection } \\
\text { provinces }\end{array}$ & No. & $\begin{array}{l}\text { Kayit } \\
\text { No. } \\
\text { Accession } \\
\text { No. } \\
\end{array}$ & $\begin{array}{l}\text { Toplama } \\
\text { yeri } \\
\text { Collection } \\
\text { provinces }\end{array}$ & No. & $\begin{array}{l}\text { Kayıt } \\
\text { No. } \\
\text { Accession } \\
\text { No. } \\
\end{array}$ & $\begin{array}{l}\text { Toplama } \\
\text { yeri } \\
\text { Collection } \\
\text { provinces }\end{array}$ \\
\hline 1 & TR 48464 & Şanlıurfa & 25 & TR 68931 & Aksaray & 49 & TR 50155 & Kütahya & 73 & TR 42513 & Çanakkale \\
\hline 2 & TR 75422 & Bilecik & 26 & TR 42603 & Tekirdağ & 50 & TR 42600 & İstanbul & 74 & TR 42579 & Edirne \\
\hline 3 & TR 42030 & Diyarbakır & 27 & TR 42549 & Çanakkale & 51 & TR 42833 & Bursa & 75 & TR 49228 & Sinop \\
\hline 4 & TR 42620 & Edirne & 28 & TR 55426 & Samsun & 52 & TR 42767 & Sakarya & 76 & TR 42509 & Çanakkale \\
\hline 5 & TR 38245 & Edirne & 29 & TR 42593 & Tekirdă̆ & 53 & TR 42954 & Balıkesir & 77 & TR 42619 & Edirne \\
\hline 6 & TR 42925 & Bursa & 30 & TR 42497 & Çanakkale & 54 & TR 76879 & Bilecik & 78 & TR 42597 & Tekirdă̆ \\
\hline 7 & TR 39564 & Afyon & 31 & TR 42592 & Tekirdă & 55 & TR 79487 & Afyon & 79 & TR 42662 & Kırklareli \\
\hline 8 & TR 38109 & Balıkesir & 32 & TR 42599 & İstanbul & 56 & TR 38177 & Çanakkale & 80 & TR 42610 & Edirne \\
\hline 9 & TR 42547 & Çanakkale & 33 & TR 38145 & Çanakkale & 57 & TR 42551 & Çanakkale & 81 & TR 42611 & Edirne \\
\hline 10 & TR 42681 & Tekirdă̆ & 34 & TR 38127 & Balıkesir & 58 & TR 42566 & Edirne & 82 & TR 42859 & Bursa \\
\hline 11 & TR 42530 & Çanakkale & 35 & TR 42669 & Kurklareli & 59 & TR 38181 & Tekirdă̆ & 83 & TR 42640 & Kırklareli \\
\hline 12 & TR 42553 & Çanakkale & 36 & TR 42571 & Edirne & 60 & TR 42510 & Çanakkale & 84 & TR 42862 & Bursa \\
\hline 13 & TR 42552 & Çanakkale & 37 & TR 42956 & Balıkesir & 61 & TR 42565 & Edirne & 85 & TR 42665 & Kurklareli \\
\hline 14 & TR 42541 & Çanakkale & 38 & TR 42661 & Kurklareli & 62 & TR 49175 & Samsun & 86 & TR 42557 & Çanakkale \\
\hline 15 & TR 42570 & Edirne & 39 & TR 42869 & Bursa & 63 & TR 42696 & İstanbul & 87 & TR 42578 & Edirne \\
\hline 16 & TR 42519 & Çanakkale & 40 & TR 42590 & Tekirdăg & 64 & TR 38144 & Çanakkale & 88 & TR 42651 & Kırklareli \\
\hline 17 & TR 42521 & Çanakkale & 41 & TR 42672 & Tekirdağ & 65 & TR 42556 & Çanakkale & 89 & TR 42542 & Çanakkale \\
\hline 18 & TR 50160 & Kütahya & 42 & TR 81768 & Samsun & 66 & TR 42633 & Kırklareli & 90 & TR 42940 & Balıkesir \\
\hline 19 & TR 47810 & Adiyaman & 43 & TR 42917 & Bursa & 67 & TR 66997 & Kırklareli & 91 & TR 42548 & Çanakkale \\
\hline 20 & TR 42540 & Çanakkale & 44 & TR 50219 & Burdur & 68 & TR 42718 & Sakarya & 92 & TR 42973 & Balıkesir \\
\hline 21 & TR 42511 & Çanakkale & 45 & TR 42554 & Çanakkale & 69 & TR 55445 & Samsun & 93 & TR 42608 & Tekirdağ \\
\hline 22 & TR 42572 & Edirne & 46 & TR 42555 & Çanakkale & 70 & TR 42717 & Sakarya & 94 & TR 50248 & Denizli \\
\hline 23 & TR 42683 & İstanbul & 47 & TR 42506 & Çanakkale & 71 & TR 42514 & Çanakkale & & & \\
\hline 24 & TR 42550 & Çanakkale & 48 & TR 48459 & Şanlıurfa & 72 & TR 42621 & Edirne & & & \\
\hline
\end{tabular}


Tane boyu (mm): Her parsele ait 1000 tane örneklerinden tesadüfi olarak seçilen 10 tohumun arka ve uç noktaları arasında kalan mesafe kumpas ile ölçülerek ortalama değer alınmıştır.

Tane eni (mm): Her parsele ait 1000 tane örneklerinden tesadüfi olarak seçilen ve tane boyu ölçümü yapılan 10 tohumun en geniş yeri kumpas ile ölçülerek ortalama değer alınmıştır.
Gövde alt çapı (mm): Her parselde tesadüfi olarak seçilen 10 bitkide, gövdenin kök boğazı mesafesinin üzerinde kalan 2 inci ve 3 üncü boğum arasında kumpas ile yapılan ölçümün ortalama değeri olarak alınmıştır.

Gövde üst çapı (mm): Her parselde tesadüfi olarak seçilen 10 bitkide, gövdenin tablaya giriş yerinin eğim noktasında kumpas ile yapılan ölçümün ortalama değeri olarak alınmıştır.

Çizelge 2. Üzerinde çalışılan karakterler (Anonymous, 1985; 2000).

Table 2. The observed characters (Anonymous, 1985; 2000).

\begin{tabular}{|c|c|c|c|}
\hline $\begin{array}{l}\text { Karakter No. } \\
\text { Character No. }\end{array}$ & $\begin{array}{l}\text { Morfolojik karakterler } \\
\text { Morphometric characteristics }\end{array}$ & $\begin{array}{l}\text { Karakter No. } \\
\text { Character No. }\end{array}$ & $\begin{array}{l}\text { Morfolojik karakterler } \\
\text { Morphometric characteristics }\end{array}$ \\
\hline A-1 & $\begin{array}{l}\% 50 \text { çiçeklenme gün sayıs } 1 \\
\text { Days to } 50 \% \text { flowering }\end{array}$ & A-23 & $\begin{array}{l}\text { Yaprak lateral damarlar arası açı } \\
\text { Angle of lateral veins of leaf }\end{array}$ \\
\hline A-2 & $\begin{array}{l}\text { Fizyolojik olum gün sayısı } \\
\text { Days to physiological maturity }\end{array}$ & A-24 & $\begin{array}{l}\text { Yaprak tüylülüğ̈̈ } \\
\text { Leaf haireness }\end{array}$ \\
\hline A-3 & $\begin{array}{l}\text { Bitki boyu }(\mathrm{cm}) \\
\text { Plant height }(\mathrm{cm})\end{array}$ & A-25 & $\begin{array}{l}\text { Tabla duruşu/açısı } \\
\text { Head angle }\end{array}$ \\
\hline A-4 & $\begin{array}{l}\text { Gövde alt çapı }(\mathrm{mm}) \\
\text { Stem lower part diameter }(\mathrm{mm})\end{array}$ & A-26 & $\begin{array}{l}\text { Tabla açısı } \\
\text { Head inclination }\end{array}$ \\
\hline A-5 & $\begin{array}{l}\text { Gövde üst çapı }(\mathrm{mm}) \\
\text { Stem upper part diameter }(\mathrm{mm})\end{array}$ & A-27 & $\begin{array}{l}\text { Tabla şekli } \\
\text { Head shape }\end{array}$ \\
\hline A-6 & $\begin{array}{l}\text { Yaprak eni }(\mathrm{cm}) \\
\text { Leaf width }(\mathrm{cm})\end{array}$ & A-28 & $\begin{array}{l}\text { Tane rengi } \\
\text { Seed color }\end{array}$ \\
\hline A-7 & $\begin{array}{l}\text { Yaprak boyu }(\mathrm{cm}) \\
\text { Leaf length }(\mathrm{cm})\end{array}$ & A-29 & $\begin{array}{l}\text { Tane şekli } \\
\text { Seed shape }\end{array}$ \\
\hline A-8 & $\begin{array}{l}\text { Tabla çap } 1(\mathrm{~cm}) \\
\text { Head diameter }(\mathrm{cm})\end{array}$ & A-30 & $\begin{array}{l}\text { Tohum kenarındaki çizgililik durumu } \\
\text { Presence of streaking at the edge of the seed }\end{array}$ \\
\hline A-9 & $\begin{array}{l}\text { Tane eni }(\mathrm{mm}) \\
\text { Seed width }(\mathrm{mm})\end{array}$ & A-31 & $\begin{array}{l}\text { Tohum kenarındaki çizgiler } \\
\text { Streaking at the edge of the seed }\end{array}$ \\
\hline A-10 & $\begin{array}{l}\text { Tane boyu }(\mathrm{mm}) \\
\text { Seed length }(\mathrm{mm})\end{array}$ & A-32 & $\begin{array}{l}\text { Tohum kenarındaki çizgilerin rengi } \\
\text { Color of streaking at the edge of the seed }\end{array}$ \\
\hline A-11 & $\begin{array}{l}\text { Tek bitki verimi ( } \mathrm{g} / \text { tabla }) \\
\text { Single plant seed yield }\left(\mathrm{g} \mathrm{head}^{-1}\right)\end{array}$ & A-33* & $\begin{array}{l}\text { Yaprak dişliliğinin dağılışı } \\
\text { Leaf serration }\end{array}$ \\
\hline A-12 & $\begin{array}{l}1000 \text { tane ağırlığ }(\mathrm{g}) \\
1000 \text { seed weight }(\mathrm{g})\end{array}$ & A-34* & $\begin{array}{l}\text { Yaprakta antosiyanin renklenmesi } \\
\text { Anthocyanin coloration of leaf }\end{array}$ \\
\hline A-13 & $\begin{array}{l}\text { Yağ oranı }(\%) \\
\text { Oil percentage }(\%)\end{array}$ & A-35* & $\begin{array}{l}\text { Tabla disk çiçekleri stigmada antosiyanin varlığ } 1 \\
\text { The presence of anthocian in flowers }\end{array}$ \\
\hline A-14 & $\begin{array}{l}\text { Bitki gelişmesi (Vigorite) } \\
\text { Plant vigority }\end{array}$ & A-36* & $\begin{array}{l}\text { Polen miktarı } \\
\text { The amount of pollen }\end{array}$ \\
\hline A-15 & $\begin{array}{l}\text { Üniformite } \\
\text { Uniformity }\end{array}$ & A-37* & $\begin{array}{l}\text { Ayçiçeği tipi (yağlık-çerezlik) } \\
\text { Type of sunflowers (oilseed-confectionary) }\end{array}$ \\
\hline A-16 & $\begin{array}{l}\text { Bitki dallanmas1 } \\
\text { Branching }\end{array}$ & A-38* & $\begin{array}{l}\text { Sapta yaprak dağılımı } \\
\text { Leaf distribution on stalk }\end{array}$ \\
\hline A-17 & $\begin{array}{l}\text { Sap tüylülüğü } \\
\text { Hairiness of stem }\end{array}$ & A-39* & $\begin{array}{l}\text { Tabla disk çiçek rengi } \\
\text { Head disk flower color }\end{array}$ \\
\hline A-18 & $\begin{array}{l}\text { Yaprak rengi } \\
\text { Leaf color }\end{array}$ & A- $40 *$ & $\begin{array}{l}\text { Tabla dil çiçek rengi } \\
\text { Petal color }\end{array}$ \\
\hline A-19 & $\begin{array}{l}\text { Yaprak şekli } \\
\text { Leaf shape }\end{array}$ & A- $41^{*}$ & $\begin{array}{l}\text { Tabla disk çiçeklerde polen oluşumu } \\
\text { Formation of pollen in disc flowers }\end{array}$ \\
\hline A-20 & $\begin{array}{l}\text { Yaprak kulakçıklar } \\
\text { Leaf auricules }\end{array}$ & A- $42 *$ & $\begin{array}{l}\text { Polen fertilliği } \\
\text { Pollen fertility }\end{array}$ \\
\hline A-21 & $\begin{array}{l}\text { Yaprak kenar dişliliği } \\
\text { Leaf edge serration }\end{array}$ & A- $43 *$ & $\begin{array}{l}\text { Polen rengi } \\
\text { Pollen color }\end{array}$ \\
\hline A-22 & $\begin{array}{l}\text { Yaprak kabarcıklı̆̆ } \\
\text { Leaf blistering }\end{array}$ & & \\
\hline
\end{tabular}

*Birbirinden farklılık görülmeyen karakterlerdir (Characters that do not differ from each other). 


\section{İstatistiksel analizler}

Deneme 3 adet yağllk standart çeşit (TURAY, EGE 2001, TUNCA) kullanılarak Augmented deneme deseninde kurulmuştur. Deneme alanlarına ait bilgiler Çizelge 3'de detaylı olarak verilmiştir. Elde edilen verilerin maksimum-minimum değerleri, varyans1, standart sapmas1 ve CV (\%) değerleri JMP paket programı kullanılarak istatistiki olarak belirlenmiştir (Anonymous, 2007). Bütün özellikler Kümeleme Analizi (KÜME Analizi)'ne tabi tutularak dendogramlarla populasyonlar arası farklilıklar ortaya konulmuştur (Ward, 1963). Ayrıca, populasyonlar arası varyasyon çoklu değişken analizlerinden Ana Bileşen Analizi (ABA) [Principal Component Analysis (PCA)] ile ortaya konulmuştur (Sneath ve Sokal, 1973; Clifford ve Stephenson, 1975; Tan, 1983). Kantitatif karakterlere ait frekans değerleri hesaplanmıştır (Steel ve Torrie, 1980).

\section{BULGULAR}

\section{Yağlık ayçiçeği genetik kaynaklarının ABA (Ana Bileşen Analizi) analizi}

Yağlık ayçiçeği populasyonlarında ayçiçeği tipi, yaprak kenar dişliliğinin dağılışı, yaprakta antosiyanin renklenmesi, tabla disk çiçekleri stigmada antosiyanin varlığı, polen miktarı, i, sapta yaprak dağılımı, tabla disk çiçek rengi, tabla dil çiçek rengi, tabla disk çiçeklerde polen oluşumu, polen fertilliği ve polen rengi karakterlerinde (Karakter no: 33-43) örnekler arasında herhangi bir farklılık görülmemiştir. Bu nedenle yağlık ayçiçeği örneklerinde analizler geriye kalan 32 karakterde (Çizelge 2) Ana Bileşen Analizi (ABA) yapılmıştır. Analizi yapılan karakterler; bitki gelişmesi (vigorite), \% 50 çiçeklenme gün sayısı, fizyolojik olum gün sayıs1, üniformite, bitki boyu $(\mathrm{cm})$, gövde alt çap1 (mm), gövde üst çap1 $(\mathrm{mm})$, bitki dallanması, sap tüylülüğü, yaprak rengi, yaprak şekli, yaprak kulakçıklar, yaprak kenar dişliliği, yaprak kabarcıklığı, yaprak eni $(\mathrm{cm})$, yaprak boyu (cm), yaprak lateral damarlar arası açı, yaprak tüylülüğü, tabla çapı $(\mathrm{cm})$, tabla duruşu, tabla açısı, tabla şekli, tane eni $(\mathrm{mm})$, tane boyu $(\mathrm{mm})$, tek bitki verimi (g/tabla), yağ oranı (\%), 1000 tane ağırlığ1 (g), tane rengi, tane şekli, tohum kenarındaki çizgililik durumu, tohum kenarındaki çizgiler ve tohum kenarındaki çizgilerin rengidir. Analizde yer alan ve yukarıda belirtilen 32 karakter yönünden oluşan 12 ana bileşene ait ağırlıklı değerler Çizelge 4 'de verilmiştir.

Çizelge 3. Parsel ölçüleri.

Table 3. Parcel dimensions.

\begin{tabular}{ll} 
Parsel sıra sayısı (No. of rows in parcels) & 2 \\
Hasatta tabla sayısı (No. of heads at harvest) & 10 \\
Sira arası mesafesi (Space between the rows) & $70 \mathrm{~cm}$. \\
Sira üzeri mesafesi (Plant space on the rows) & $35 \mathrm{~cm}$. \\
Sirada ocak sayısı (No. of plants on the row) & 22 \\
Ekimde parsel uzunluğu (Parcel length at sowing) & $7,70 \mathrm{~m}$. \\
Ekimde parsel genişliği (Parcel widts at sowing) & $1,40 \mathrm{~m}$. (iki sira) \\
Parsel alanı (Parcel area) & $1,40 \mathrm{~m} . \mathrm{x} 7,70 \mathrm{~m} .=10,78 \mathrm{~m}^{2}$ \\
Denemede yer alan genetik kaynaklar materyali sayısı & 94 adet \\
(No. of genetic resources material) & 3 adet yağlık (TURAY, EGE 2001, TUNCA) \\
Denemede yer alan standart çeşit sayısı (Control variety) & \\
\hline
\end{tabular}


Çizelge 4. Yağlık ayçiçeği örneklerine ait morfolojik özelliklerin ana bileşen değerleri.

Table 4. Principle components of the morphological characters of oilseed sunflowers.

\begin{tabular}{|c|c|c|c|c|c|c|c|c|c|c|c|c|c|}
\hline $\begin{array}{l}\text { Karakter } \\
\text { No. } \\
\text { Character } \\
\text { No. }\end{array}$ & $\begin{array}{l}\text { Morfolojik karakterler } \\
\text { Morphometric characteristics }\end{array}$ & $\begin{array}{l}\text { ABA-1 } \\
\text { PRIN } \\
1\end{array}$ & $\begin{array}{l}\text { ABA-2 } \\
\text { PRIN } \\
2\end{array}$ & $\begin{array}{l}\text { ABA-3 } \\
\text { PRIN } \\
3\end{array}$ & $\begin{array}{l}\text { ABA-4 } \\
\text { PRIN } \\
4\end{array}$ & $\begin{array}{l}\text { ABA-5 } \\
\text { PRIN } \\
5\end{array}$ & $\begin{array}{l}\text { ABA-6 } \\
\text { PRIN } \\
6\end{array}$ & $\begin{array}{l}\text { ABA-7 } \\
\text { PRIN } \\
7\end{array}$ & $\begin{array}{l}\text { ABA- } 8 \\
\text { PRIN } \\
8\end{array}$ & $\begin{array}{l}\text { ABA-9 } \\
\text { PRIN } \\
9\end{array}$ & $\begin{array}{l}\text { ABA-10 } \\
\text { PRIN } \\
10\end{array}$ & $\begin{array}{l}\text { ABA-11 } \\
\text { PRIN } \\
11\end{array}$ & $\begin{array}{l}\text { ABA-12 } \\
\text { PRIN } \\
12\end{array}$ \\
\hline A-1 & $\begin{array}{l}\% 50 \text { çiçeklenme gün sayısı } \\
\text { Days to } 50 \% \text { flowering }\end{array}$ & $-0,231$ & $-0,211$ & 0,095 & 0,220 & $-0,010$ & $-0,060$ & 0,255 & $-0,037$ & 0,210 & 0,084 & 0,067 & $-0,034$ \\
\hline A-2 & $\begin{array}{l}\text { Fizyolojik olum gün sayısı } \\
\text { Days to physiological maturity }\end{array}$ & $-0,249$ & 0,022 & 0,275 & 0,316 & 0,002 & $-0,020$ & $-0,018$ & 0,097 & 0,133 & $-0,019$ & 0,131 & 0,162 \\
\hline A-3 & $\begin{array}{l}\text { Bitki boyu }(\mathrm{cm}) \\
\text { Plant height }(\mathrm{cm})\end{array}$ & $-0,245$ & $-0,140$ & 0,239 & $-0,013$ & $-0,165$ & 0,091 & 0,172 & $-0,142$ & 0,043 & $-0,134$ & 0,069 & $-0,061$ \\
\hline A-4 & $\begin{array}{l}\text { Gövde alt çap1 }(\mathrm{mm}) \\
\text { Stem lower part diameter }(\mathrm{mm})\end{array}$ & 0,371 & $-0,010$ & 0,169 & 0,048 & 0,075 & 0,019 & $-0,027$ & 0,040 & 0,013 & 0,037 & $-0,042$ & 0,031 \\
\hline A-5 & $\begin{array}{l}\text { Gövde üst çapı }(\mathrm{mm}) \\
\text { Stem upper part diameter }(\mathrm{mm})\end{array}$ & 0,062 & $-0,022$ & $-0,089$ & $-0,115$ & 0,138 & 0,253 & 0,397 & 0,202 & 0,314 & $-0,253$ & $-0,296$ & 0,045 \\
\hline A-6 & $\begin{array}{l}\text { Yaprak eni }(\mathrm{cm}) \\
\text { Leaf width }(\mathrm{cm}) \\
\end{array}$ & 0,345 & 0,035 & 0,045 & $-0,030$ & 0,149 & $-0,055$ & $-0,161$ & 0,030 & 0,157 & $-0,077$ & $-0,058$ & 0,110 \\
\hline A-7 & $\begin{array}{l}\text { Yaprak boyu }(\mathrm{cm}) \\
\text { Leaf length }(\mathrm{cm})\end{array}$ & 0,275 & $-0,099$ & 0,146 & $-0,187$ & $-0,093$ & $-0,102$ & 0,061 & 0,386 & 0,086 & 0,153 & $-0,051$ & 0,066 \\
\hline A-8 & $\begin{array}{l}\text { Tabla çap } 1(\mathrm{~cm}) \\
\text { Head diameter }(\mathrm{cm})\end{array}$ & 0,203 & $-0,139$ & 0,178 & $-0,052$ & $-0,147$ & $-0,292$ & 0,113 & 0,407 & 0,072 & 0,131 & $-0,032$ & $-0,013$ \\
\hline A-9 & $\begin{array}{l}\text { Tane eni }(\mathrm{mm}) \\
\text { Seed width }(\mathrm{mm})\end{array}$ & 0,313 & $-0,121$ & 0,081 & 0,162 & 0,038 & 0,208 & 0,080 & $-0,302$ & 0,110 & 0,003 & 0,078 & 0,105 \\
\hline A-10 & $\begin{array}{l}\text { Tane boyu }(\mathrm{mm}) \\
\text { Seed length }(\mathrm{mm})\end{array}$ & 0,042 & $-0,289$ & 0,212 & 0,052 & 0,070 & 0,311 & $-0,275$ & 0,128 & $-0,140$ & 0,066 & 0,026 & $-0,203$ \\
\hline A-11 & $\begin{array}{l}\text { Tek bitki verimi }(\mathrm{g} / \mathrm{tabla}) \\
\text { Single plant yield }\left(\mathrm{g} \mathrm{head}^{-1}\right)\end{array}$ & $-0,171$ & $-0,037$ & 0,172 & $-0,213$ & 0,234 & 0,093 & $-0,077$ & $-0,009$ & 0,337 & 0,206 & $-0,138$ & 0,207 \\
\hline A-12 & $\begin{array}{l}1000 \text { tane ağırlı̆̆ }(\mathrm{g}) \\
1000 \text { seed weight }(\mathrm{g})\end{array}$ & $-0,143$ & 0,387 & $-0,024$ & $-0,007$ & 0,196 & $-0,105$ & 0,102 & 0,038 & $-0,055$ & 0,022 & $-0,041$ & $-0,015$ \\
\hline A-13 & $\begin{array}{l}\text { Yağ oranı }(\%) \\
\text { Oil percentage }(\%)\end{array}$ & 0,215 & $-0,171$ & 0,256 & 0,134 & 0,156 & 0,235 & $-0,093$ & $-0,224$ & $-0,054$ & $-0,053$ & 0,065 & $-0,029$ \\
\hline A-14 & $\begin{array}{l}\text { Bitki gelişmesi (Vigorite) } \\
\text { Plant vigority }\end{array}$ & $-0,232$ & 0,030 & 0,264 & 0,210 & 0,054 & $-0,226$ & $-0,130$ & 0,213 & $-0,015$ & 0,022 & 0,094 & 0,153 \\
\hline A-15 & $\begin{array}{l}\text { Üniformite } \\
\text { Uniformity }\end{array}$ & 0,101 & $-0,056$ & $-0,219$ & 0,435 & $-0,128$ & 0,118 & 0,024 & 0,058 & $-0,190$ & $-0,110$ & $-0,183$ & $-0,008$ \\
\hline A-16 & $\begin{array}{l}\text { Bitki dallanması } \\
\text { Branching }\end{array}$ & 0,101 & $-0,015$ & 0,078 & $-0,327$ & 0,337 & $-0,068$ & $-0,195$ & $-0,090$ & $-0,076$ & $-0,149$ & 0,310 & 0,092 \\
\hline A-17 & $\begin{array}{l}\text { Sap tüylülüğü } \\
\text { Hairiness of stem }\end{array}$ & $-0,104$ & 0,147 & 0,080 & $-0,242$ & $-0,106$ & 0,249 & 0,144 & 0,003 & $-0,300$ & 0,238 & $-0,143$ & 0,404 \\
\hline A-18 & $\begin{array}{l}\text { Yaprak rengi } \\
\text { Leaf color }\end{array}$ & $-0,111$ & 0,061 & $-0,035$ & 0,201 & 0,344 & 0,234 & $-0,151$ & 0,161 & $-0,025$ & $-0,304$ & $-0,184$ & 0,133 \\
\hline A-19 & $\begin{array}{l}\text { Yaprak şekli } \\
\text { Leaf shape }\end{array}$ & $-0,013$ & 0,164 & 0,185 & 0,125 & 0,257 & $-0,209$ & 0,086 & $-0,079$ & 0,266 & $-0,067$ & $-0,143$ & $-0,486$ \\
\hline A-20 & $\begin{array}{l}\text { Yaprak kulakçıklar } \\
\text { Leaf auricules }\end{array}$ & 0,076 & 0,106 & 0,020 & 0,031 & $-0,155$ & 0,206 & 0,428 & $-0,064$ & $-0,030$ & $-0,022$ & 0,349 & 0,041 \\
\hline A-21 & $\begin{array}{l}\text { Yaprak kenar dişliliği } \\
\text { Leaf edge serration }\end{array}$ & 0,052 & $-0,077$ & 0,111 & $-0,163$ & 0,010 & $-0,030$ & 0,282 & 0,199 & $-0,152$ & $-0,478$ & 0,333 & $-0,158$ \\
\hline A-22 & $\begin{array}{l}\text { Yaprak kabarcıklığ } \\
\text { Leaf blistering }\end{array}$ & 0,157 & $-0,016$ & $-0,007$ & 0,135 & 0,176 & $-0,030$ & 0,249 & $-0,069$ & $-0,242$ & 0,484 & $-0,136$ & $-0,321$ \\
\hline A-23 & $\begin{array}{l}\text { Yaprak lateral damarlar arası açı } \\
\text { Angle of lateral veins of leaf }\end{array}$ & $-0,023$ & 0,073 & 0,129 & 0,064 & 0,329 & 0,093 & 0,168 & 0,016 & 0,007 & 0,322 & 0,404 & 0,084 \\
\hline A-24 & $\begin{array}{l}\text { Yaprak tüylülüğ̈̈ } \\
\text { Leaf hairiness }\end{array}$ & 0,074 & 0,192 & 0,417 & 0,070 & $-0,215$ & 0,017 & $-0,055$ & $-0,018$ & $-0,219$ & $-0,112$ & $-0,154$ & 0,039 \\
\hline A-25 & $\begin{array}{l}\text { Tabla duruşu } \\
\text { Head inclination }\end{array}$ & 0,010 & 0,241 & 0,160 & $-0,247$ & $-0,050$ & 0,274 & 0,085 & $-0,081$ & 0,155 & 0,002 & $-0,183$ & $-0,178$ \\
\hline A-26 & $\begin{array}{l}\text { Tabla açısı } \\
\text { Head angle }\end{array}$ & 0,149 & 0,418 & 0,046 & 0,044 & 0,050 & 0,016 & $-0,006$ & 0,087 & $-0,093$ & $-0,052$ & 0,080 & $-0,074$ \\
\hline A-27 & $\begin{array}{l}\text { Tabla şekli } \\
\text { Head shape }\end{array}$ & 0,234 & $-0,036$ & $-0,071$ & 0,189 & $-0,132$ & $-0,177$ & 0,076 & $-0,213$ & 0,352 & $-0,023$ & 0,028 & 0,365 \\
\hline A-28 & $\begin{array}{l}\text { Tane rengi } \\
\text { Seed color }\end{array}$ & $-0,117$ & $-0,370$ & 0,010 & $-0,146$ & $-0,113$ & 0,154 & $-0,088$ & 0,141 & 0,028 & 0,033 & $-0,001$ & $-0,169$ \\
\hline A-29 & $\begin{array}{l}\text { Tane şekli } \\
\text { Seed shape }\end{array}$ & $-0,231$ & $-0,211$ & 0,095 & 0,220 & $-0,010$ & $-0,060$ & 0,255 & $-0,037$ & 0,210 & 0,084 & 0,067 & $-0,034$ \\
\hline A-30 & $\begin{array}{l}\text { Tohum kenar çizgililik durumu } \\
\text { Presence of streaking at the edge of the seed }\end{array}$ & $-0,249$ & 0,022 & 0,275 & 0,316 & 0,002 & $-0,020$ & $-0,018$ & 0,097 & 0,133 & $-0,019$ & 0,131 & 0,162 \\
\hline A-31 & $\begin{array}{l}\text { Tohum kenarındaki çizgiler } \\
\text { Streaking at the edge of the seed }\end{array}$ & $-0,245$ & $-0,140$ & 0,239 & $-0,013$ & $-0,165$ & 0,091 & 0,172 & $-0,142$ & 0,043 & $-0,134$ & 0,069 & $-0,061$ \\
\hline A-32 & $\begin{array}{l}\text { Tohum kenarındaki çizgilerin rengi } \\
\text { Color of streaking at the edge of the seed }\end{array}$ & 0,371 & $-0,010$ & 0,169 & 0,048 & 0,075 & 0,019 & $-0,027$ & 0,040 & 0,013 & 0,037 & $-0,042$ & 0,031 \\
\hline
\end{tabular}


ABA sonucunda elde edilen ana bileşenlere ait öz (eigen) değerleri ve bunların varyans yüzdeleri ile yı̆̆malı varyansları hesaplanmıştır. Analiz sonunda ilk 12 ana bileşenin öz değerleri 4,857 ile 0,934 arasında bulunmuştur. $\mathrm{Bu}$ bileşenler toplam varyansın \% 77,875'ini oluşturmuştur (Çizelge 5).

Toplam varyansın \%26,628'ini oluşturan birinci ve ikinci ana bileşenlerde (Çizelge 5) bir büyük grup ve hemen yanında küçük başka bir grup oluşmuştur (Şekil 1). Birinci ve ikinci ana bileşeni oluşturan karakterler bakımından uç değerlerde olan ve oluşan iki grup dışında kalan örnekler ise dağınık bir dağılım göstermişlerdir. Birinci ana bileşenin oluşmasında yaprak eni $(0,345)$, tane eni $(0,313)$ ve tohum kenarındaki çizgilerin rengi $(0,371)$ ağırlıklı olarak etkili olurken ikinci ana bileşenin oluşmasında 1000 tane ağırlığ $(0,387)$ ve tabla açısı $(0,418)$ ağırlıklı olarak etkili olmuştur (Çizelge 4).

Toplam varyansın \%16,192'si ile değerlendirilen üçüncü ve dördüncü ana bileşenlerde de benzer bir tablo gözlenmiştir (Çizelge 5). Bileşenleri oluşturan karakterler bakımından bir ana grup ve daha küçük ikinci bir grup oluşumunun yanı sıra bunların dışında yer alan az sayıda örneğin dağınık dağılım gösterdiği belirlenmiştir (Şekil 2).

Şekil 3'de görülen beşinci ana bileşeni oluşumunda bitki dallanmas1 $(0,337)$, yaprak rengi $(0,344)$, yaprak dişliliğgin dağılışı $(0,316)$ ve yaprak lateral damarlar arası açı $(0,329)$ değerleri etkili olurken

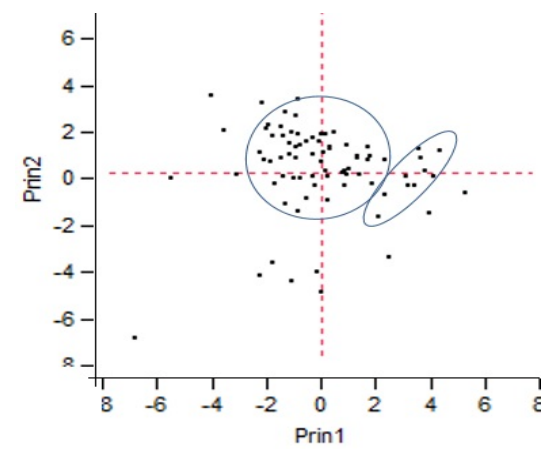

Şekil 1. Örneklerin 1. (PRIN 1) ve 2. (PRIN 2) ana bileşenlerdeki dağılımı.

Figure 1. Distributions and grouping of the samples on PRIN 1 and PRIN 2. altıncı bileşenin oluşumunda polen miktarı $(0,423)$ ağırlıklı olarak etkili olmuşstur (Çizelge 4).

Toplam varyansın \%9,508'i ile değerlendirilen (Çizelge 5) yedinci ve sekizinci ana bileşenlerde de benzer bir tablo gözlenmiş kesiksiz bir dağılım gösteren tek bir grup ile bunların dişında dağınık yer alan örneklerden oluşan bir dağılım belirlenmiştir (Şekil 4). Yedinci ana bileşenin oluşmasında gövde üst çap1 $(0,397)$ ve yaprak kulakçıklar $(0,428)$ etkili olurken sekizinci ana bileşenin oluşmasında yaprak boyu $(0,386)$ ve tabla çapı $(0,407)$ değerleri ağırlıklı olarak etkili olmuştur (Çizelge 4).

Çizelge 5. Yağlık ayçiçeği örneklerinin öz (eigen) değerleri, varyans yüzdeleri ve bunlara ait yığmalı varyansları.

Table 5. Principle components, eigen values, variance percentages and cumulative varience values of oilseed sunflowers.

\begin{tabular}{|c|c|c|c|}
\hline $\begin{array}{l}\text { Ana bileşenler } \\
\text { (ABA) } \\
\text { Principle } \\
\text { components } \\
\text { (PCA) }\end{array}$ & $\begin{array}{c}\text { Eigen } \\
\text { değerleri } \\
\text { Eigen values }\end{array}$ & $\begin{array}{c}\text { Varyans } \\
\text { yüzdesi } \\
\text { Variance } \\
\text { percentage } \\
(\%)\end{array}$ & $\begin{array}{c}\text { Yığmalı } \\
\text { varyans } \\
\text { Cumulative } \\
\text { varience } \\
(\%)\end{array}$ \\
\hline ABA 1 / PRIN 1 & 4,857 & 15,178 & 15,178 \\
\hline ABA 2 / PRIN 2 & 3,664 & 11,450 & 26,628 \\
\hline ABA 3 / PRIN 3 & 3,038 & 9,493 & 36,121 \\
\hline ABA 4 / PRIN 4 & 2,144 & 6,699 & 42,820 \\
\hline ABA 5 / PRIN 5 & 1,959 & 6,121 & 48,941 \\
\hline ABA 6 / PRIN 6 & 1,635 & 5,109 & 54,050 \\
\hline ABA 7 / PRIN 7 & 1,542 & 4,820 & 58,870 \\
\hline ABA 8 / PRIN 8 & 1,500 & 4,688 & 63,558 \\
\hline ABA 9 / PRIN 9 & 1,320 & 4,126 & 67,684 \\
\hline ABA 10 / PRIN 10 & 1,230 & 3,842 & 71,526 \\
\hline ABA 11 / PRIN 11 & 1,097 & 3,429 & 74,955 \\
\hline ABA 12 / PRIN 12 & 0,934 & 2,920 & 77,875 \\
\hline
\end{tabular}

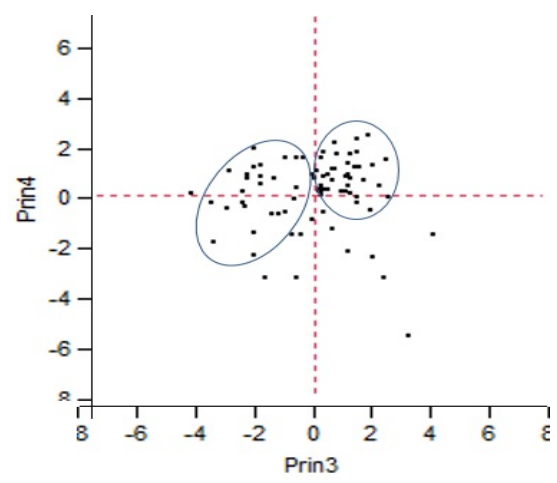

Şekil 2. Örneklerin 3. (PRIN 3) ve 4. (PRIN 4) ana bileşenlerdeki dağılımı

Figure 2. Distributions and grouping of the samples on PRIN 3 and PRIN 4. 


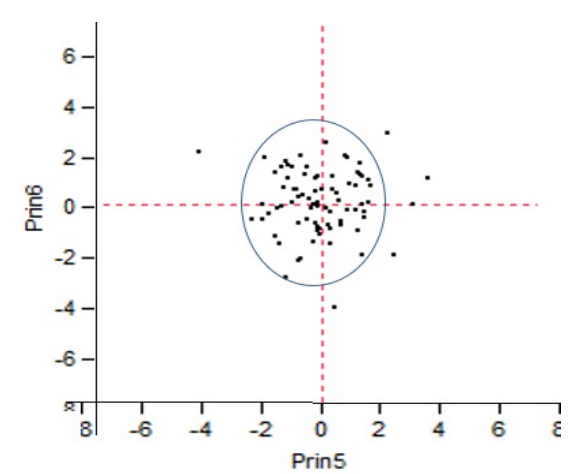

Şekil 3. Örneklerin 5. (PRIN 5) ve 6. (PRIN 6) ana bileșenlerdeki dağılımı

Figure 3. Distributions and grouping of the samples on PRIN 5 and PRIN 6.

Dokuzuncu ve onuncu ana bileșenlerde önceki tablolar ile benzer bir form gözlenmiş (Şekil 5); gövde üst çapı $(0,314)$, tek bitki verimi $(0,337)$ ve tabla şekli $(0,352)$ (PRIN 9'u oluşturan değerler) ile yaprak kabarcıklığı $(0,484)$ ve yaprak lateral damarlar arası açı $(0,322)$ (PRIN 10'u oluşturan değerler) bakımından kesiksiz bir dağglım gösteren tek bir grup oluşumu gözlenmiştir (Çizelge 4).

Son olarak toplam varyansin $\%$ 3,429'u ile değerlendirilen on birinci ve toplam varyansın \% 2,920 'si ile değerlendirilen on ikinci ana bileşenlerde ise (Çizelge 5); bitki dallanması $(0,310)$, yaprak kulakçıklar $(0,349)$, yaprak kenar dişliliği $(0,333)$ ve yaprak lateral damarlar arası açı $(0,404)$ (PRIN 11'i oluşturan değerler); sap

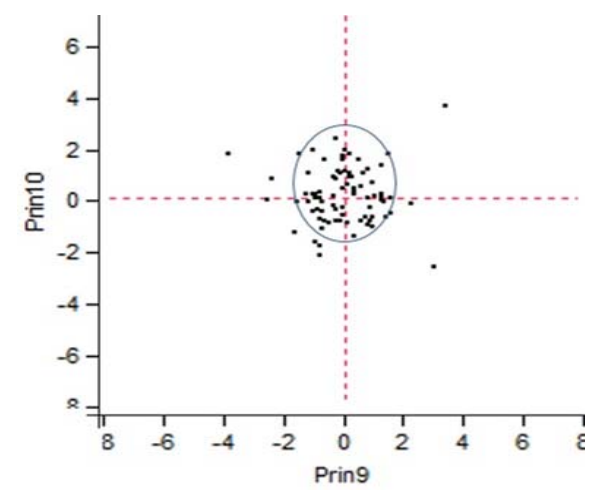

Şekil 5. Örneklerin 9. (PRIN 9) ve 10. (PRIN 10) ana bileşenlerdeki dağılımı

Figure 5. Distributions and grouping of the samples on PRIN 9 and PRIN 10.

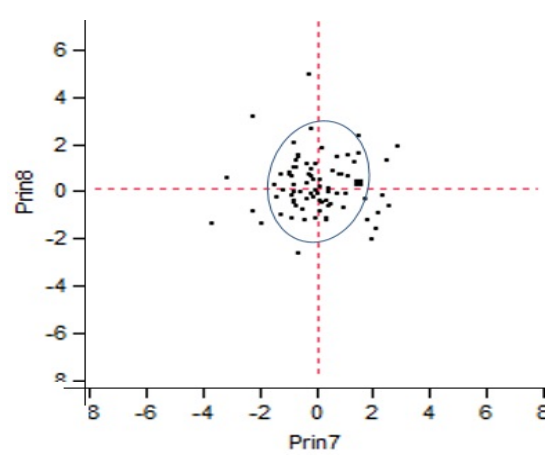

Şekil 4. Örneklerin 7. (PRIN 7) ve 8. (PRIN 8) ana bileșenlerdeki dağılımı.

Figure 4. Distributions and grouping of the samples on PRIN 7 and PRIN 8.

tüylülüğü $(0,404)$ ve tabla şekli $(0,365)$ ( PRIN 12 'i oluşturan değerler) bakımından tek bir grup oluşmuş ve örneklerin tamamına yakını bu grup içerisinde toplanmış iken sadece bir adet örnek gruptan ayrı bir duruş göstermiştir (Şekil 6).

ABA analizinde her bir karakter çifti için korelasyon matrisleri elde edilmiştir (Çizelge 6). Tablo incelendiğinde en yüksek korelasyonun tabla duruşu ile tabla açısı arasında $(0,855)$ ortaya çıktığ1 görülmüştür. Bu değeri yaprak boyu ile tabla çapı $(0,763)$ ve gövde alt çapı ile yaprak eni arasındaki $(0,747)$ korelasyon izlemektedir. Birbiri ile ilişkili korelasyon gösteren karakterler Çizelge 6'da verilmiştir. Üzerinde çalışlan karakterlerin açıklamaları ise Çizelge 2'de verilmiştir.

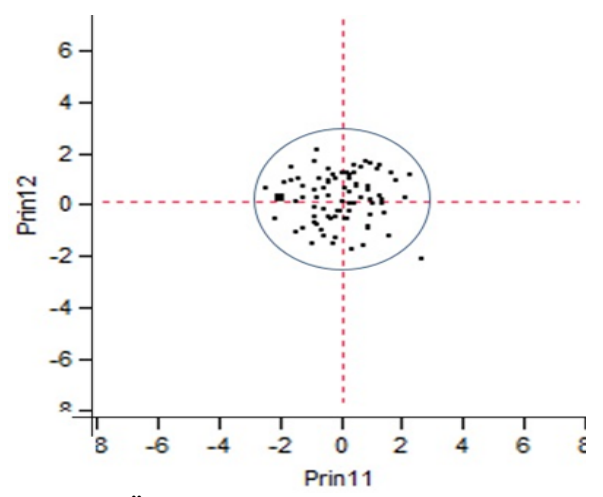

Şekil 6. Örneklerin 11. (PRIN 11) ve 12. (PRIN 12) ana bileşenlerdeki dağılımı.

Figure 6. Distributions and grouping of the samples on PRIN 11 and PRIN 12. 

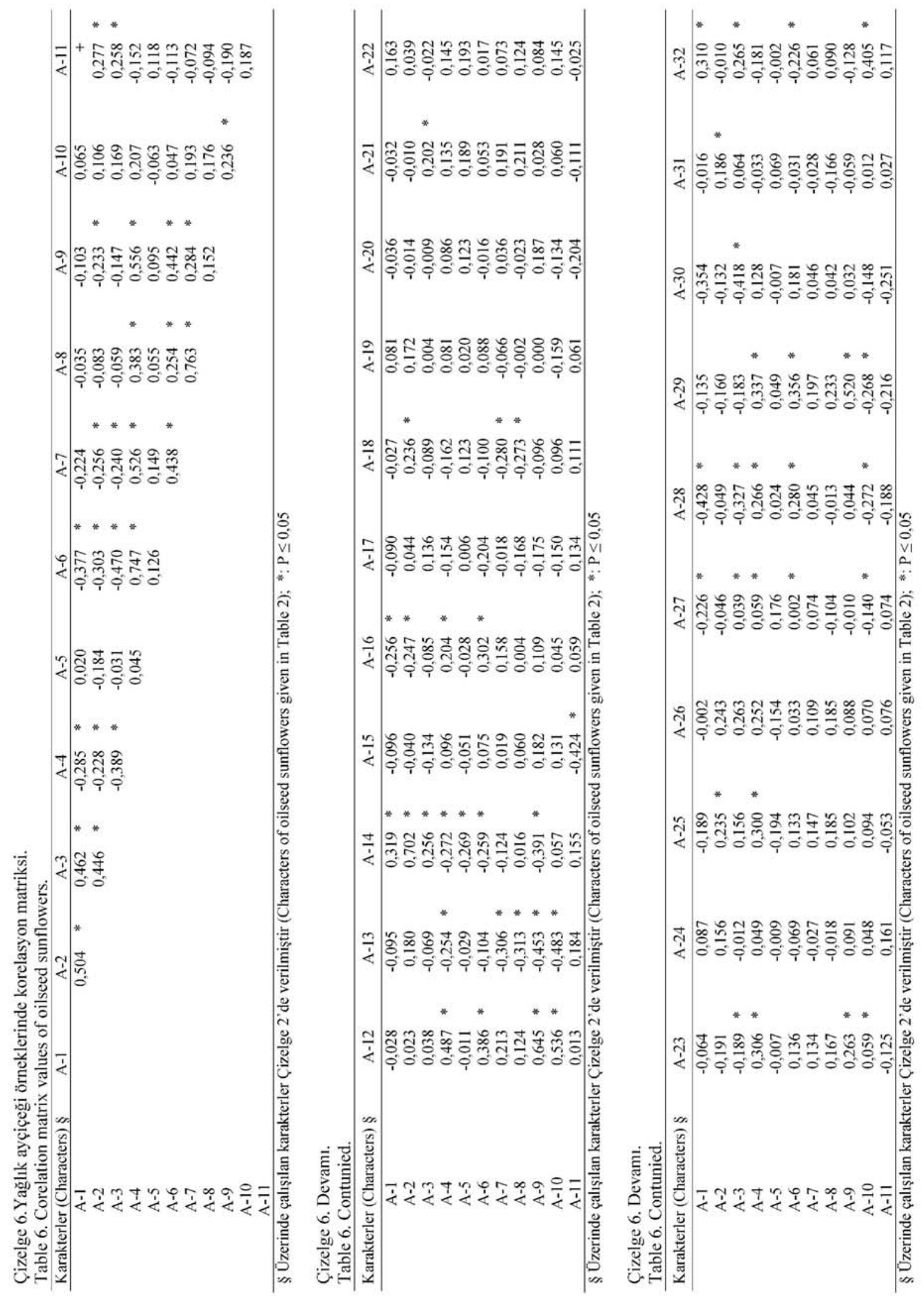

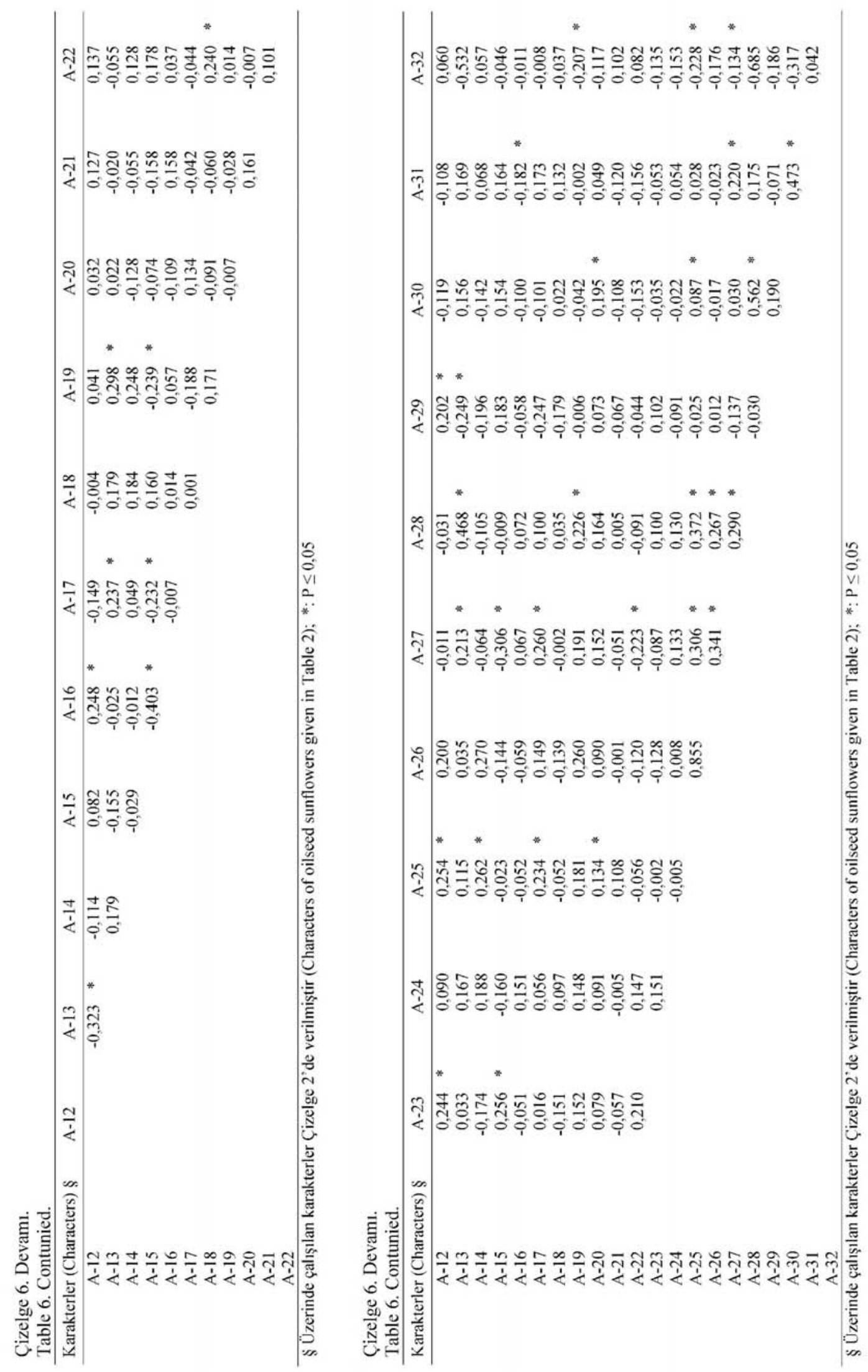
Yağlık ayçiçeğinde kümeleme (CLUSTER) analizi

Yağlık ayçiçeği populasyonlar, 32 karakter bakımından öklit uzaklığı dikkate alınarak Kümeleme analizi yapılarak değerlendirilmiştir (Ward, 1963). Yağlık ayçiçeği örneklerinin dağılım dendogramı Şekil 7'de verilmiştir. Dendogram incelendiğinde 8 adet KÜME oluştuğu görülmektedir. Örneklerin çoğunluğu büyük bir grup altında alt gruplar oluşturarak dağılım gösterirken az sayıda örnek tek bir alt grup oluşturmuştur (Şekil 7). Yağlı örneklerin dahil oldukları kümeler Çizelge 7'de verilmiştir.

Çizelge 7. Yağlık örneklerde kümeleme dağılımı.

Table 7. Clusters of oilseed sunflower land races.

\begin{tabular}{|c|c|}
\hline Küme-1/Cluster-1 & Küme-2/Cluster-2 \\
\hline $\begin{array}{l}\text { BGK-13, BGK-14, BGK-15, } \\
\text { BGK-17, BGK-23, BGK-24, } \\
\text { BGK-27, BGK-29, BGK-31, } \\
\text { BGK-35, BGK-40, BGK-41, } \\
\text { BGK-75, BGK-79, BGK-84, } \\
\text { BGK-94 }\end{array}$ & $\begin{array}{l}\text { BGK-3, BGK-11, BGK-12, } \\
\text { BGK-16, BGK-33, BGK-38, } \\
\text { BGK-51, BGK-52 }\end{array}$ \\
\hline Küme-3/Cluster-3 & Küme-4/Cluster-4 \\
\hline BGK-61 & $\begin{array}{l}\text { BGK-8, BGK-28, BGK-32, } \\
\text { BGK-34, BGK-37, BGK-42, } \\
\text { BGK-43, BGK-44, BGK-55, } \\
\text { BGK-62, BGK-66, BGK-71, } \\
\text { BGK-80, BGK-83, BGK-85 }\end{array}$ \\
\hline Küme-5/Cluster-5 & Küme-6/Cluster-6 \\
\hline ST-1, ST-2, ST-3 & $\begin{array}{l}\text { BGK-2, BGK-9, BGK-20, } \\
\text { BGK-22, BGK-25, BGK-30, } \\
\text { BGK-36, BGK-57, BGK-58, } \\
\text { BGK-64, BGK-65, BGK-67, } \\
\text { BGK-68, BGK-69, BGK-72, } \\
\text { BGK-76, BGK-77, BGK-78, } \\
\text { BGK-81, BGK-82, BGK-86, } \\
\text { BGK-87, BGK-88, BGK-89, } \\
\text { BGK-90, BGK-91, BGK-92, } \\
\text { BGK-93, BGK-95, BGK-96 }\end{array}$ \\
\hline Küme-7/Cluster-7 & Küme-8/Cluster-8 \\
\hline $\begin{array}{l}\text { BGK-19, BGK-50, BGK-53, } \\
\text { BGK-54, BGK-73 }\end{array}$ & BGK-1 \\
\hline
\end{tabular}

\section{Yağlık ayçiçeği genetik kaynaklarının kantitatif} karakterler bakımından değerlendirilmesi

Çalışmada yer alan örneklerde \% 50 çiçeklenme gün sayıs1, fizyolojik olum gün sayıs1, bitki boyu $(\mathrm{cm})$, gövde alt çapı $(\mathrm{mm})$, gövde üst çapı $(\mathrm{mm})$, yaprak eni $(\mathrm{cm})$, yaprak boyu $(\mathrm{cm})$, tabla çap1 $(\mathrm{cm})$, tane eni $(\mathrm{mm})$, tane boyu $(\mathrm{mm})$, tek bitki verimi (g/tabla), yağ oranı (\%) ve 1000 tane ağırlığı (g) karakterleri bakımından gerekli hesaplamalar yapılmış ve sonuçları yorumlanmıştır. Yine yağlı ayçiçeği populasyonları için kantitatif karakterlerin frekansları hesaplanmış ve bu frekanslara ait içerik Çizelge 8'de, bu karakterlerde yapılan ölçümlere ait maksimum, minimum, standart sapma ve CV değerleri de Çizelge 9'da verilmiştir.

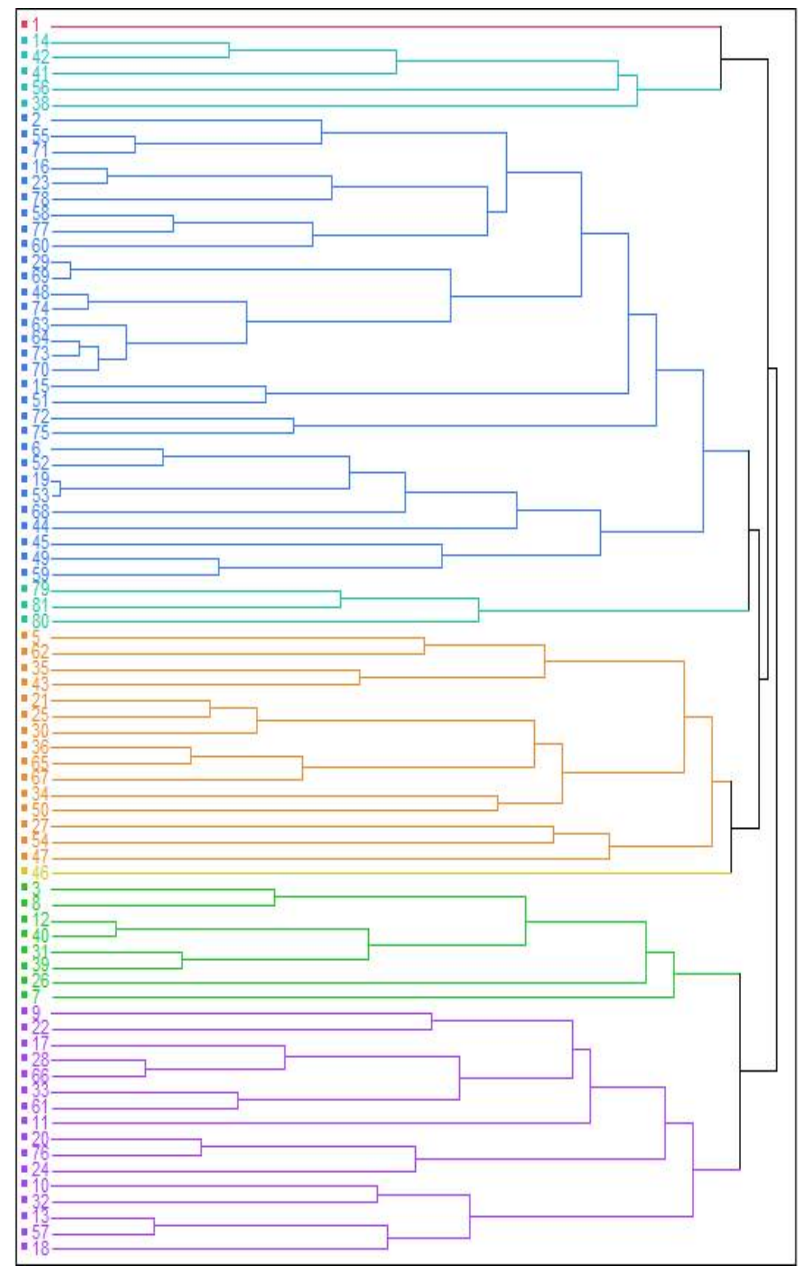

Şekil 7. Yağlık ayçiçeği genetik kaynaklarının dağılım dendogramı. Figure 7. Distribution dendogram of oilseed sunflower genetic resources.

Çiçeklenme gün sayısı: $\% 50$ çiçeklenme gün sayısı bakımından örneklerin büyük kısmının \%50,7) 60,5-65,5 gün arasında değişim gösterdiği gözlenmiştir (Şekil 8; Çizelge 8). Örneklerin min. 51 ve mak. 81 gün arasında olduğu tespit edilmiştir (Çizelge 9).

Fizyolojik olum gün sayısı: Örneklerin büyük çoğunluğu erkenci grupta yer almış olup $(84,0$ 101,2 gün) en erkenci olan 3 adet örnek olduğu gözlenmiştir (Şekil 9; Çizelge 8). Örneklerin min. 84 ve mak. 110 gün arasında olduğu tespit edilmiştir (Çizelge 9). 
Çizelge 8. Yağlık ayçiçeği genetik kaynakları örneklerinde incelenen kantitatif karakterlere ait frekans tablosu.

Table 8 Frequency table of quantitative characters of oilseed sunflower samples of genetic resources.

\begin{tabular}{|c|c|c|c|c|}
\hline $\begin{array}{l}\text { Karakter No. } \\
\text { Character No. }\end{array}$ & $\begin{array}{l}\text { Karakter } \\
\text { Character }\end{array}$ & $\begin{array}{l}\text { Aralık } \\
\text { Range }\end{array}$ & $\begin{array}{l}\text { Frekans } \\
\text { Frequency }\end{array}$ & $\%$ \\
\hline \multirow[t]{7}{*}{ A-1 } & $\% 50$ çiçeklenme gün sayısı / Days to $50 \%$ flowering & & & \\
\hline & 1 & $50,1-55,5$ & 7 & 8,6 \\
\hline & 2 & $55,5-60,5$ & 21 & 25,9 \\
\hline & 3 & $60,5-65,5$ & 41 & 50,7 \\
\hline & 4 & $65,5-70,5$ & 10 & 12,4 \\
\hline & 5 & $70,5-75,5$ & 1 & 1,2 \\
\hline & 6 & $75,5-81,0$ & 1 & 1,2 \\
\hline \multirow[t]{7}{*}{$\mathrm{A}-2$} & Fizyolojik olum gün sayısı / Days to physiological maturity & & & \\
\hline & 1 & $84,0-88,3$ & 1 & 3,7 \\
\hline & 2 & $88,3-92,6$ & 13 & 16,1 \\
\hline & 3 & $92,6-96,9$ & 7 & 8,6 \\
\hline & 4 & $96,9-101,2$ & 30 & 37,0 \\
\hline & 5 & $101,2-105,5$ & 13 & 16,1 \\
\hline & 6 & $105,5-110,0$ & 15 & 18,5 \\
\hline \multirow[t]{7}{*}{$\mathrm{A}-3$} & Bitki boyu $(\mathrm{cm}) /$ Plant height $(\mathrm{cm})$ & & & \\
\hline & 1 & $130,6-151,6$ & 12 & 14,8 \\
\hline & 2 & $151,6-172,6$ & 34 & 42,0 \\
\hline & 3 & $172,6-193,6$ & 23 & 28,4 \\
\hline & 4 & $193,6-214,6$ & 11 & 13,6 \\
\hline & 5 & $214,6-235,6$ & 0 & 0 \\
\hline & 6 & $235,6-256,6$ & 1 & 1,2 \\
\hline \multirow[t]{7}{*}{$\mathrm{A}-4$} & Gövde alt çapı (mm) / Stem lower part diameter (mm) & & & \\
\hline & 1 & $25,08-30,55$ & 3 & 3,7 \\
\hline & 2 & $30,55-36,02$ & 27 & 33,3 \\
\hline & 3 & $36,02-41,49$ & 32 & 39,4 \\
\hline & 4 & $41,49-46,96$ & 14 & 17,2 \\
\hline & 5 & $46,96-52,43$ & 4 & 5,2 \\
\hline & 6 & $52,43-57,91$ & 1 & 1,2 \\
\hline \multirow[t]{7}{*}{$\mathrm{A}-5$} & Gövde üst çapı $(\mathrm{mm})$ / Stem upper part diameter (mm) & & & \\
\hline & 1 & $14,73-17,73$ & 5 & 6,3 \\
\hline & 2 & $17,73-20,73$ & 23 & 28,4 \\
\hline & 3 & $20,73-23,73$ & 31 & 38,3 \\
\hline & 4 & $23,73-26,73$ & 17 & 20,9 \\
\hline & 5 & $26,73-29,73$ & 3 & 3,7 \\
\hline & 6 & $29,73-32,73$ & 2 & 2,4 \\
\hline \multirow[t]{7}{*}{ A-6 } & Yaprak eni $(\mathrm{cm}) /$ Leaf width $(\mathrm{cm})$ & & & \\
\hline & 1 & $27,40-31,73$ & 16 & 19,8 \\
\hline & 2 & $37,73-36,06$ & 26 & 32,1 \\
\hline & 3 & $36,06-40,39$ & 29 & 35,8 \\
\hline & 4 & $40,39-44,72$ & 9 & 11,1 \\
\hline & 5 & $44,72-49,05$ & 0 & 0 \\
\hline & 6 & $49,05-53,40$ & 1 & 1,2 \\
\hline \multirow[t]{7}{*}{$\mathrm{A}-7$} & Yaprak boyu $(\mathrm{cm}) /$ Leaf length $(\mathrm{cm})$ & & & \\
\hline & 1 & $24,10-30,31$ & 21 & 25,9 \\
\hline & 2 & $30,31-36,52$ & 48 & 59,4 \\
\hline & 3 & $36,52-42,73$ & 10 & 12,3 \\
\hline & 4 & $42,73-48,94$ & 1 & 1,2 \\
\hline & 5 & $48,94-55,15$ & 0 & 0 \\
\hline & 6 & $55,15-61,36$ & 1 & 1,2 \\
\hline \multirow[t]{7}{*}{$\mathrm{A}-8$} & Tabla çap1 $(\mathrm{cm}) /$ Head diameter $(\mathrm{cm})$ & & & \\
\hline & 1 & $17,55-20,35$ & 5 & 6,3 \\
\hline & 2 & $20,35-23,15$ & 18 & 22,8 \\
\hline & 3 & $23,15-25,95$ & 34 & 41,8 \\
\hline & 4 & $25,95-28,75$ & 16 & 19,0 \\
\hline & 5 & $28,75-31,55$ & 5 & 6,3 \\
\hline & 6 & $31,55-34,75$ & 3 & 3,7 \\
\hline \multirow[t]{7}{*}{$\mathrm{A}-9$} & Tane eni $(\mathrm{mm})$ / Seed width $(\mathrm{mm})$ & & & \\
\hline & 1 & $4,75-5,30$ & 1 & 2,4 \\
\hline & 2 & $5,30-5,85$ & 6 & 7,4 \\
\hline & 3 & $5,85-6,40$ & 13 & 16,1 \\
\hline & 4 & $6,40-6,95$ & 33 & 40,8 \\
\hline & 5 & $6,95-7,52$ & 20 & 24,7 \\
\hline & 6 & $7,52-8,07$ & 7 & 8,6 \\
\hline
\end{tabular}


Çizelge 8. Devam.

Table 8. Continued.

\begin{tabular}{|c|c|c|c|c|}
\hline $\begin{array}{l}\text { Karakter No. } \\
\text { Character No. }\end{array}$ & $\begin{array}{l}\text { Karakter } \\
\text { Character }\end{array}$ & $\begin{array}{l}\text { Aralık } \\
\text { Range }\end{array}$ & $\begin{array}{c}\text { Frekans } \\
\text { Frequency }\end{array}$ & $\%$ \\
\hline \multirow[t]{7}{*}{ A-10 } & Tane boyu $(\mathrm{mm})$ / Seed length $(\mathrm{mm})$ & & & \\
\hline & 1 & $9,61-10,71$ & 6 & 7,4 \\
\hline & 2 & $10,71-11,81$ & 29 & 35,8 \\
\hline & 3 & $11,81-12,91$ & 30 & 37,1 \\
\hline & 4 & $12,91-14,01$ & 13 & 16,1 \\
\hline & 5 & $14,01-15,11$ & 1 & 1,2 \\
\hline & 6 & $15,11-16,23$ & 2 & 2,4 \\
\hline \multirow[t]{7}{*}{ A-11 } & Tek bitki verimi (g/tabla) / Single plant yield & & & \\
\hline & 1 & $0,47-20,49$ & 17 & 21,0 \\
\hline & 2 & $20,49-40,51$ & 32 & 39,5 \\
\hline & 3 & $40,51-60,53$ & 21 & 25,9 \\
\hline & 4 & $60,53-80,55$ & 7 & 8,6 \\
\hline & 5 & $80,55-100,57$ & 3 & 3,7 \\
\hline & 6 & $100,57-120,59$ & 1 & 1,2 \\
\hline \multirow[t]{7}{*}{ A-12 } & 1000 tane ağırlığı $(\mathrm{g}) / 1000$ seed weight $(\mathrm{g})$ & & & \\
\hline & 1 & $44,25-58,71$ & 6 & 7,4 \\
\hline & 2 & $58,71-73,17$ & 8 & 9,9 \\
\hline & 3 & $73,17-87,63$ & 27 & 33,3 \\
\hline & 4 & $87,63-102,09$ & 31 & 38,4 \\
\hline & 5 & $102,09-116,55$ & 7 & 8,6 \\
\hline & 6 & $116,55-131,01$ & 2 & 2,4 \\
\hline \multirow[t]{7}{*}{$\mathrm{A}-13$} & Yağ oranı $(\%)$ / Oil percentage $(\%)$ & & & \\
\hline & 1 & $12,70-17,78$ & 7 & 8,9 \\
\hline & 2 & $17,70-22,86$ & 11 & 13,9 \\
\hline & 3 & $22,80-27,94$ & 25 & 31,6 \\
\hline & 4 & $27,90-33,02$ & 20 & 25,3 \\
\hline & 5 & $33,00-38,10$ & 13 & 16,5 \\
\hline & 6 & $38,10-43,18$ & 3 & 3,8 \\
\hline
\end{tabular}

Çizelge 9. Yağlık ayçiçeği genetik kaynakları örneklerinde incelenen kantitatif karakterlere ait minimum, maksimum, standart sapma ve varyasyon katsayısı değerleri.

Table 9. Minimum, maximumu, standart deviation and coefficient of variation values of quantitative characters of oilseed sunflower samples of genetic resources.

\begin{tabular}{|c|c|c|c|c|}
\hline $\begin{array}{l}\text { Karakterler } \\
\text { Characters }\end{array}$ & $\begin{array}{l}\text { Minimum } \\
\text { değer } \\
\text { Minimum } \\
\text { values }\end{array}$ & $\begin{array}{l}\text { Maksimum } \\
\text { değer } \\
\text { Maximum } \\
\text { values }\end{array}$ & $\begin{array}{c}\text { Standart } \\
\text { sapma } \\
\text { Standart } \\
\text { deviation }\end{array}$ & $\begin{array}{c}\text { Varyasyon } \\
\text { katsayis1 (\%) } \\
\text { Coefficient of } \\
\text { variation (\%) }\end{array}$ \\
\hline \% 50 çiçeklenme gün say1sı / Days to 50 \% flowering & 51 & 81 & 4,92 & 7,95 \\
\hline Fizyolojik olum gün sayısı / Days to physiological maturity & 84 & 110 & 6,15 & 6,19 \\
\hline Bitki boyu $(\mathrm{cm}) /$ Plant height $(\mathrm{cm})$ & 130,60 & 256,40 & 20,51 & 11,97 \\
\hline Tabla çap1 $(\mathrm{cm}) /$ Head diameter $(\mathrm{cm})$ & 17,70 & 34,70 & 3,26 & 13,14 \\
\hline Gövde alt çapı $(\mathrm{mm})$ / Stem lower part diameter (mm) & 25,08 & 57,91 & 5,01 & 12,90 \\
\hline Gövde üst çapı $(\mathrm{mm})$ / Stem upper part diameter $(\mathrm{mm})$ & 14,73 & 32,67 & 3,30 & 15,00 \\
\hline Yaprak eni $(\mathrm{cm}) /$ Leaf width $(\mathrm{cm})$ & 27,40 & 53,40 & 4,27 & 11,93 \\
\hline Yaprak boyu $(\mathrm{cm}) /$ Leaf length $(\mathrm{cm})$ & 24,10 & 61,36 & 5,02 & 15,35 \\
\hline Tane eni (mm) / Seed width (mm) & 4,75 & 8,06 & 0,66 & 9,93 \\
\hline Tane boyu (mm) / Seed length (mm) & 9,61 & 16,23 & 1,12 & 9,28 \\
\hline Tek bitki verimi (g/tabla) / Single plant yield (g/head) & 0,47 & 120,58 & 23,01 & 59,96 \\
\hline Yağ oranı $(\%) /$ Oil percentage $(\%)$ & 12,70 & 43,18 & 6,18 & 22,91 \\
\hline 1000 tane ağırlığ $(\mathrm{g}) / 1000$ seed weight $(\mathrm{g})$ & 44,25 & 131,00 & 15,75 & 18,36 \\
\hline
\end{tabular}

Gövde alt çapı ve Gövde üst çapı: 32 örnek $(\% 39,4)$ gövde alt çapı bakımından 36,02-41,49 mm'lik aralıkta yer alırken, gövde üst çapı olarak örneklerin en fazla \%38,3'ü 20,73-23,73 mm, en az \%2,4 ile 29,73-32,73 $\mathrm{mm}$ aralı̆̆ında dağ 11 ım gösterdiği gözlenmiştir (Çizelge 8, Şekil 10 ve 11). Örneklerin gövde alt çapı olarak min. 25,08 mm ile mak. 57,91 mm arasında; gövde üst çapı olarak da min. $14,73 \mathrm{~mm}$ ve mak. $32,67 \mathrm{~mm}$ arasinda olduğu tespit edilmiştir (Çizelge 9).

Bitki boyu: bitki boyu açısından yapılan değerlendirmede; 34 adet örnek 151,6-172,6 cm'lik aralıkta ilk sirada yer alırken 23 örnek 172,6-193,6 cm'lik aralıkta ikinci sirada yer almıştır (Şekil 12). Örnekler içerisinde sadece 1 adet örneğin 235,6-256,6 cm aralığında uzun boylu 
olarak yer aldığ 1 tespit edilmiştir (Çizelge 8). Örneklerin min. 130,60 ve mak. 256,40 cm arasında olduğu tespit edilmiştir (Çizelge 9).

Tabla çapı: $23,15-25,95 \mathrm{~cm}$ aralıkta 34 örnek ilk sirada yer alırken örneklerin $17,55 \mathrm{~cm}$ ile $34,75 \mathrm{~cm}$ arasında dağıldığı gözlenmiştir (Şekil 13; Çizelge 8). Örneklerin min. 17,70 ve mak. $34,70 \mathrm{~cm}$ arasında olduğu tespit edilmiştir (Çizelge 9).

Yaprak eni, yaprak boyu: Yağlik örnekler arasında yaprak eni 27,40-53,40 cm arasında (Şekil 14) değişim gösterirken örneklerin \%35,8'lik

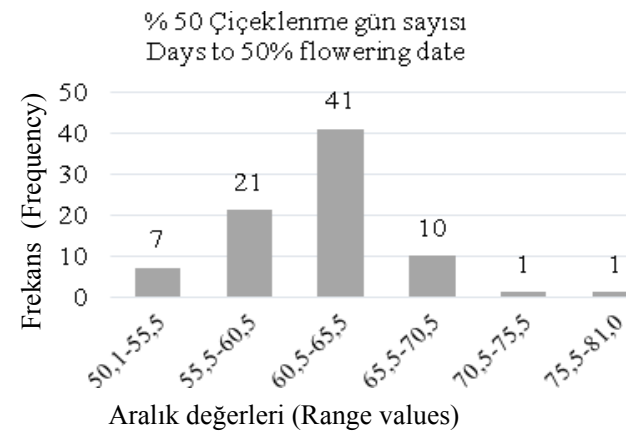

Şekil 8. \%50 çiçeklenme gün sayısı aralık değerleri. Figure 8 . Days to $50 \%$ flowering date range values.

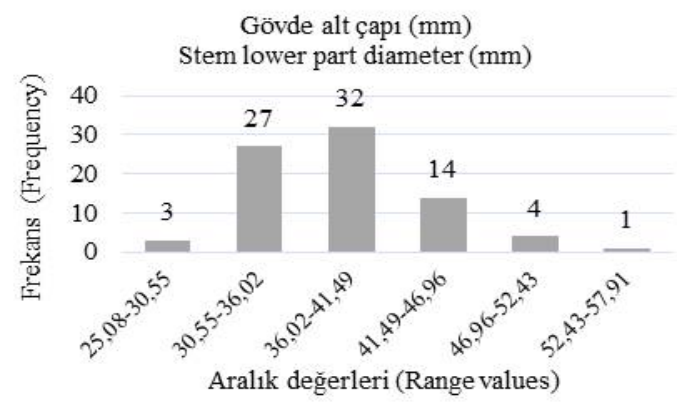

Şekil 10. Gövde alt çapı aralık değerleri (mm).

Figure 10 . Stem lower part diameter range values $(\mathrm{mm})$.

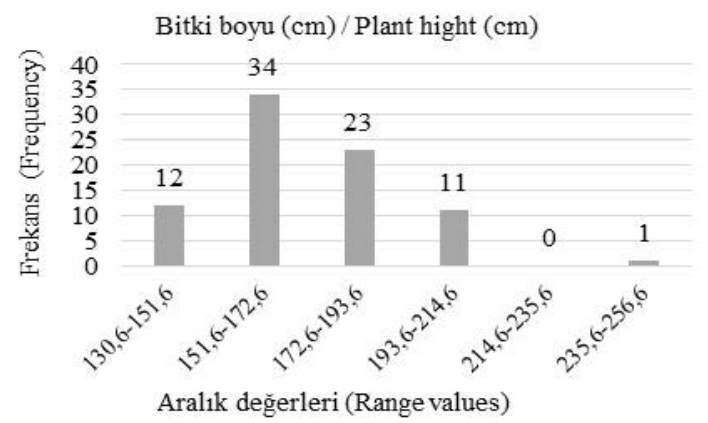

Şekil 12. Bitki boyu aralık değerleri (cm). Figure 12. Plant hight range values $(\mathrm{cm})$. kısmının 36,06-40,39 cm ile ilk sirada yer aldığ 1 sonucuna ulaşılmıştır (Çizelge 8). Yaprak boyu açısından ise örneklerin yarıdan fazlasının (48 adet) 30,31-36,52 $\mathrm{cm}$ aralığında bulunduğu gözlenmiştir (Şekil 15). Dağ 11 lım çizelgesine bakıldığında örneklerin dağılımlarının büyük oranda $(\% 97,6) \quad 24,10-42,73 \mathrm{~cm}$ arasında olduğu tespit edilmiştir (Çizelge 8). Örneklerin yaprak eni olarak min. 27,40 ve mak. 53,40 cm arasinda; yaprak boyu olarak ise min. 24,10 ve mak. 61,36 $\mathrm{cm}$ arasında olduğu tespit edilmiştir (Çizelge 9).

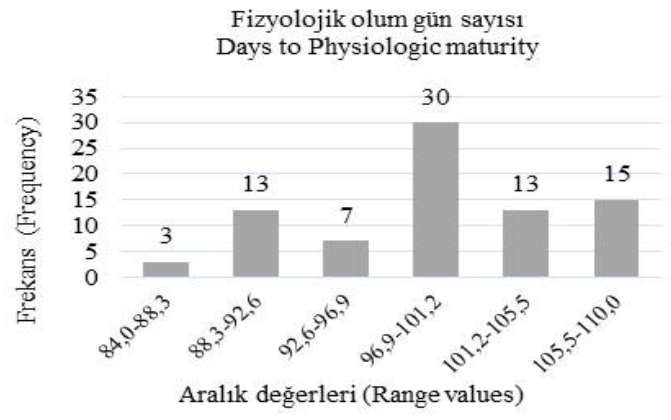

Şekil 9. Fizyolojik olum gün sayısı aralık değerleri.

Figure 9. Days to physiologic maturity date range values.

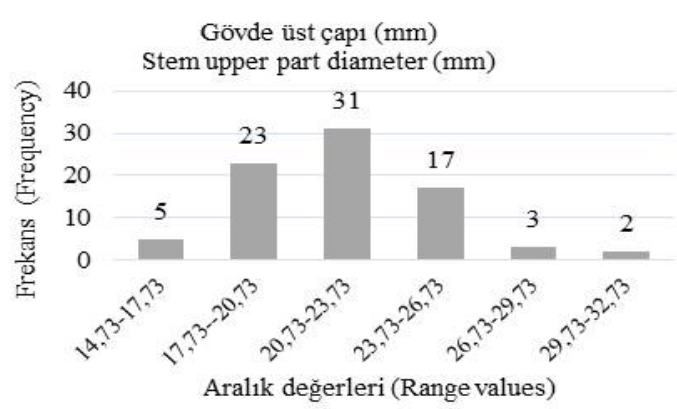

Şekil 11. Gövde üst çapı aralık değerleri (mm). Figure 11. Stem upper part diameter range values $(\mathrm{mm})$.

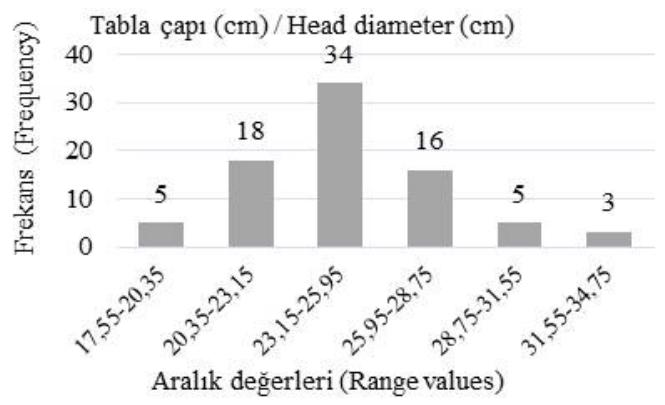

Şekil 13. Tabla çapı aralık değerleri $(\mathrm{cm})$. Figure 13. Head diameter range values $(\mathrm{cm})$. 


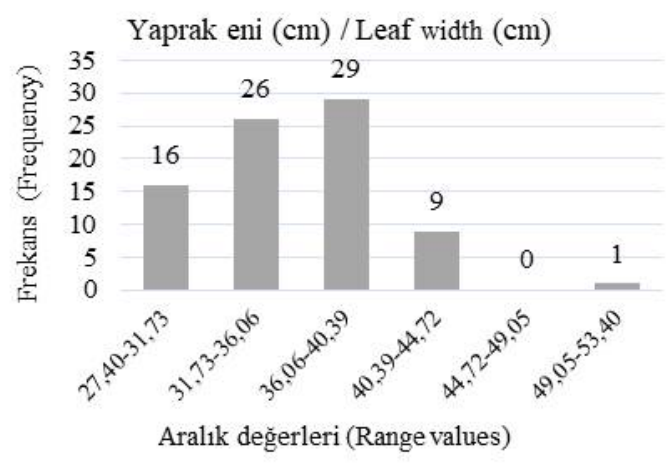

Şekil 14. Yaprak eni aralık değerleri $(\mathrm{cm})$. Figure 14. Leaf width range values $(\mathrm{cm})$.

Tane eni: Yağlık örneklerde ise; tane eni ölçümleri 4,75-8,07 cm (Çizelge 8) arasında değişim gösterirken ilk sirada $6,40-6,95 \mathrm{~cm}$ arasında yer alan 33 adet (Şekil 16) örnek yer almıştır. Örneklerin tane eni değerlerinin min. 4,75 ve mak. $8,06 \mathrm{~mm}$ arasında olduğu tespit edilmiştir (Çizelge 9).

Tane boyu: Yağlik populasyonlarda tane boyu ise; 9,61-16,23 cm (Çizelge 8) aralığında yer almış ve en uzun tane boyu $15,11-16,23 \mathrm{~cm}$ aralığında yer alan iki adet örnekte görülmüştür (Şekil 17). Örneklerin dağılımında genelde yağlık örnekler için tercih edilen boyutta yoğunluk 10,71-12,91 cm aralığında yer alan 59 adet örnekte gözlenmiştir. Örneklerin tane boyu değerlerinin min. 9,61ve mak. 16,23 mm arasında olduğu tespit edilmiştir (Çizelge 9).

1000 Tane ağırlığı: Yağlık örneklerde ise; 1000 tane ağırlığ 44,25-131,01 g (Çizelge 8) aralığında dağılım göstermiştir. İlk sırada yer alan 31 örnek 87,63-102,09 g aralığında ikinci sırada 27 örnek 73,17-87,63 g aralığında yer almıştır (Şekil 18). Örneklerin 1000 tane ağırllğg değerlerinin min.

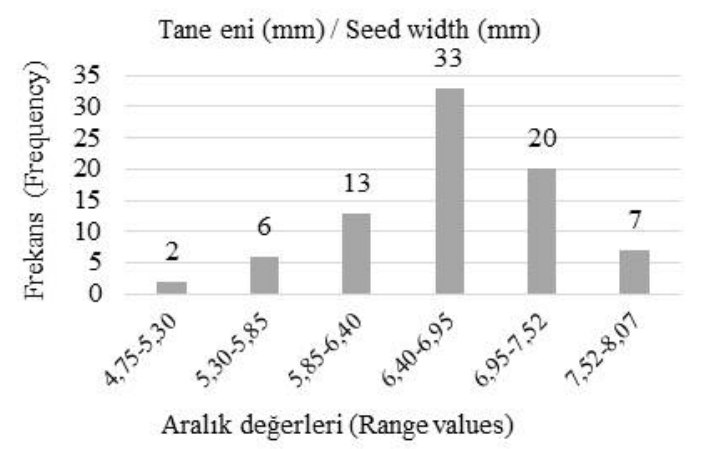

Şekil 16. Tane eni aralık değerleri $(\mathrm{mm})$. Figure 16. Seed width range values $(\mathrm{mm})$.

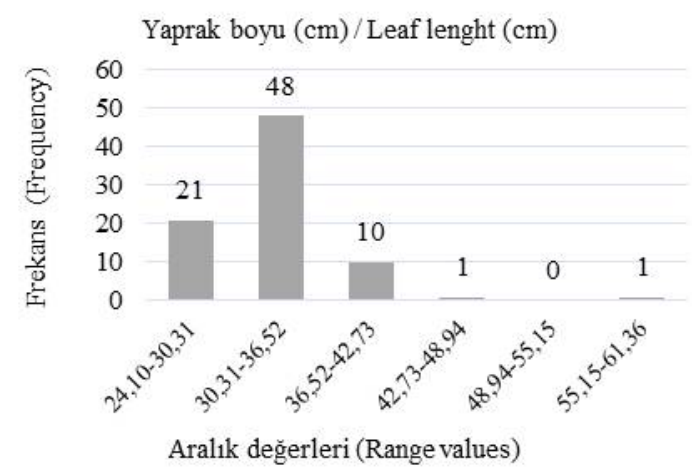

Şekil 15. Yaprak boyu aralık değerleri $(\mathrm{cm})$.

Figure 15. Leaf lenght range values $(\mathrm{cm})$.

44,25 ve mak. 131,00 g arasında olduğu tespit edilmiştir (Çizelge 9).

Tek bitki verimi: Örnekler bu özellik bakımından 0,47-120,59 g arasında geniş bir dağılım göstermiştir. İlk sırada \%39,5'lik değer (Çizelge 8) ile 20,49-40,51 $\mathrm{g}$ aralı̆̆ında yer alan 32 adet örnek yer alırken \%1,2'lik değer (Çizelge 8) ile 100,57-120,59 g aralığında bir adet örnek bulunduğu belirlenmiştir (Şekil 19). Örneklerin Tek Bitki Verimi değerlerinin min. $0,47 \mathrm{~g}$ /tabla ve mak. $120,58 \mathrm{~g} /$ tabla arasında olduğu tespit edilmiştir (Çizelge 9).

Yağ oranı: Çalışmada yer alan örneklerin yağ oranları \%12,70-43,18 arasında dağılım gösterdiği tespit edilmiştir (Çizelge 8). Örneklerin 25 adedi \%22,86-27,94 aralığında belirlenerek \% 31,6'lık dilimle ilk sırada yer almıştır (Şekil 20). Bu değeri \%27,94-33,02 aralığında olduğu belirlenen 20 adet örnek \%25,3'lük dilimle ikinci sırada takip etmiştir (Çizelge 8). Örneklerin yağ oranı değerlerinin min. $\%$ 12,70 mak. \% 43,18 arasında olduğu tespit edilmiştir (Çizelge 9).

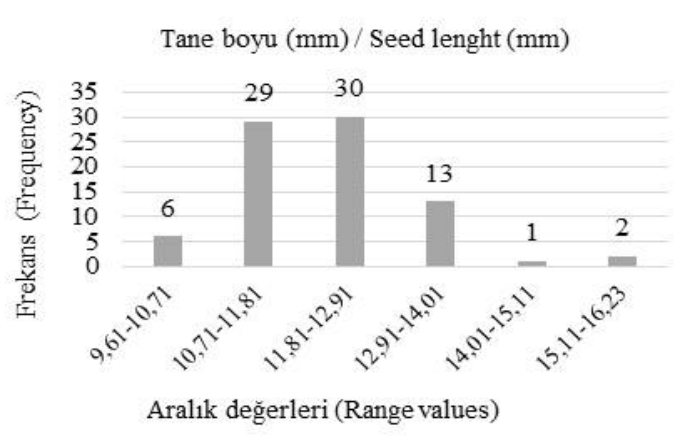

Şekil 17. Tane boyu aralık değerleri $(\mathrm{mm})$.

Figure 17. Seed lenght) range values $(\mathrm{mm})$. 


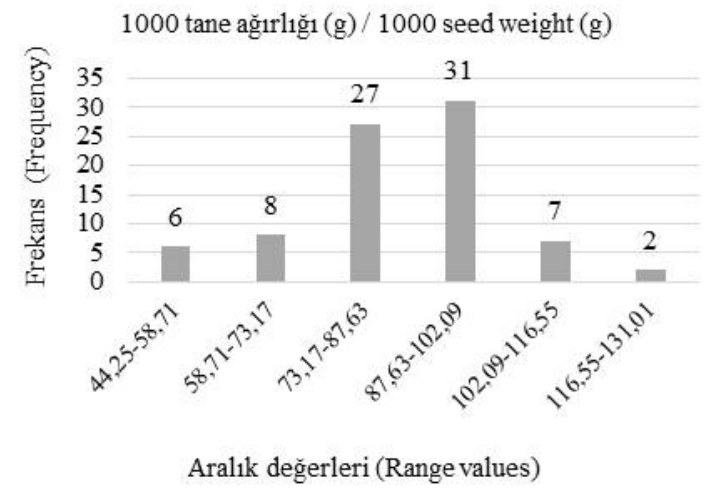

Şekil 18. 1000 tane ağırlığı aralık değerleri (g). Figure 18. 1000 seed weight range values $(\mathrm{g})$.

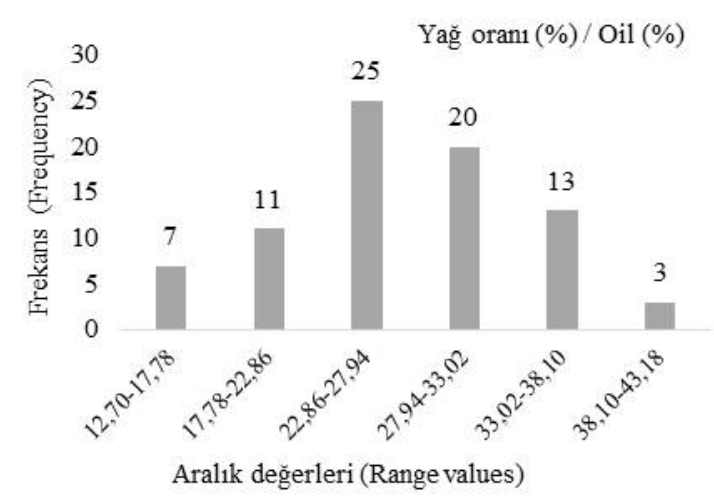

Şekil 20. Yağ oranı aralık değerleri (\%).

Figure 20. Oil percentage range values (\%).

\section{Yağlık ayçiçeği genetik kaynakalarının kalitatif karakterler bakımından değerlendirilmesi}

Yağlık ayçiçeği populasyonlarında yaprak dişliliğinin dağılış1, yaprakta antosiyanin renklenmesi, tabla disk çiçekleri stigmada antosiyanin varlığı, polen miktarı karakterlerinden örnekler arasında herhangi bir varyasyon görülmediği için frekans hesaplamalarına dahil edilmemiştir. Diğer karakterlere ilişkin frekans değerleri Çizelge 10'da verilmiştir.

Bitki gelişmesi (Vigor): $\mathrm{Bu}$ karakteri yağlik örnekler için de değerlendirecek olursak; \%71,6's1 bitki gelişimi açısından iyi bir gelişim sergilemişken $\% 7,4$ 'ü zayıf ve $\% 21$ 'i de orta seviyede bir gelişim göstermiştir (Çizelge 10).

Üniformite: Yağlık ayçiçeği populasyonlarında da yine örneklerin büyük çoğunluğunun heterojen bir

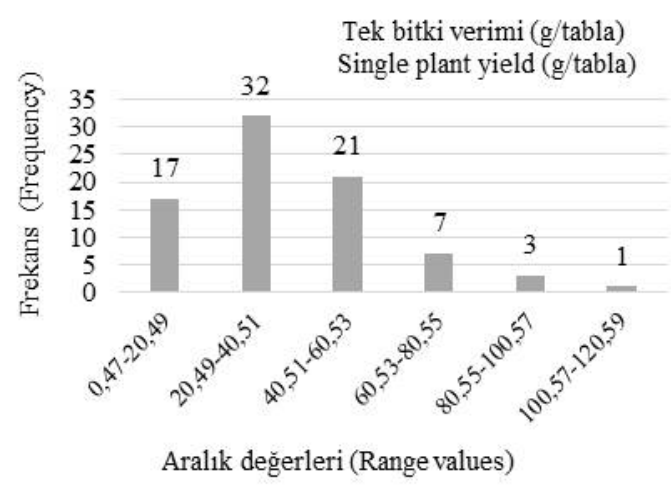

Şekil 19. Tek bitki verimi aralık değerleri (g/tabla). Figure 19. Single plant yield range values ( $\mathrm{g} /$ head).

yapıda olduğu gözlenmiştir $(\% 93,8)$. Örneklerin \% 3,7'lik kısmı üniform olarak tanımlanırken kalan $\% 2,5^{\prime}$ luk kısmı ise çok üniform olarak gruplandırılmıştır (Çizelge 10).

Bitki dallanması: Yağlık populasyonlarda örneklerin büyük çoğunluğu $(\% 81,5)$ dalsız iken bir miktar örnekte $(\% 18,5)$ dallanma olduğu tespit edilmiştir (Çizelge 10).

Sap tüylülüğü: Örneklerde $\% 67,9$ oranında belirgin seviyede tüylülük formu ilk sırada yer almıştır (Çizelge 10).

Yaprak rengi: Örneklerde ise; 65 tanesi yeşil renkli yapraklara sahip iken 16 tanesinde koyu yeşil yaprak renkli bitkiler olduğu belirlemiştir (Çizelge 10).

Yaprak şekli: Yaprak şekli açısından örnekler geniş üçgen $(\% 58)$ ve geniş üçgene yakın yuvarlak formda $(\% 42)$ bitkileri içeren populasyonlar şeklinde dağılım gösterdiği gözlenmiştir (Çizelge 10). Yağlık populasyonlara ait tüm örnekler göz önünde tutulduğunda mızrak, dar üçgene yakın mızrak, dar üçgen, geniş üçgene yakın dar üçgen, geniş üçgene yakın sivri uçlu, sivri uçlu ve yuvarlak formlarda herhangi bir örnek gözlenmemiştir.

Yaprak kulakçıklar: Örneklerde varyasyon olduğu gözlemlenmiştir. Örneklerin çoğunluğunda kulakçıklar geniş formda $(\% 55,6)$ iken çok az bir oranda olsa orta büyüklükte $(\% 2,5)$ kulakçıkların 
olduğu görülmüştür. Çok geniş formda olanların oranı ise \%41,9 olarak belirlenmiştir (Çizelge 10).

Yaprak kenar dişliliği: Yaprak kenar dişliliğinin dağılımının orta seviye $(\% 38,3)$ ile belirgin form $(\% 61,7)$ arasında olduğu gözlenmiştir (Çizelge 10).

Yaprak dişliliğin dağılışı: Örnekler arasında ise bu karakter bakımından herhangi bir varyasyon gözlenmemiştir.

Yaprak kabarcıklığı: Örneklerde de bu parametre incelendiğinde varyasyonun orta $(\% 14,8)$ ile çok güçlü formlar $(\% 17,3)$ arasında dağılım gösteren örneklerin çoğunluğu \%67,9 oranında güçlü seviyede kabarcıklı formla ilk sırada yer almıştır (Çizelge 10).

Yaprak lateral damarlar arası açı: Yağlık örneklerin büyük çoğunluğu $(\% 70,4)$ dik açı ya da dik açıya yakın formunda olduğu gözlenmiştir (Çizelge 10).

Yaprak tüylülüğü: Örneklerde dağılımın tüylü $(\% 80,2)$ ve az tüylü $(\% 19.8)$ formlar arasında olduğu gözlenmiştir (Çizelge 10).

Yaprakta antosiyanin renklenmesi: Örneklerde yaprakta antosiyanin renklenmesi hiçbir örnekte görülmemiştir.

Tabla duruşu: Örneklere ait örneklerde geniş bir varyasyon olduğu gözlemlenmiştir. Eğimli gövde üzerinde hafifçe aşağı kıvrılmış form $(\% 46,9)$ ilk sırada yer alırken, eğimli gövde üzerinde yarım aşağı dönük form $(\% 24,8)$ ikinci sırada yer almıştır. Dağ 1 lımın gövde üzerinde tam aşağı dönük form $(\% 14,8)$, dik gövde üzerinde yarım aşağ 1 dönük formların $(\% 11,1)$ yanı sıra çok düşük değerlerde de olsa sapa doğru kuvvetlice aşağı kıvrılmış form $(\% 1,2)$ ile dik form $(\% 1,2)$ arasinda olduğu tespit edilmiştir (Çizelge 10). Yağlık örneklerde yatay ve eğik formlarda herhangi bir örnek olmadığ gözlenmiştir.

Tabla șekli: Varyasyonun görüldüğü diğer bir karakter olan tabla şekli açısından yağlık örneklerin dağ $11 ı$ ınının dış bükey $(\% 50,7)$, çok belirgin diş bükey $(\% 33,3)$ ve düz $(\% 13,6)$ formlarda olduğu tespit edilmiştir. Örnekler içerisinde en düşük oran
\%2,5 ile şekilsiz form olarak gözlemlenen örneklerden oluşmuştur. Mevcut parametreler içerisinde çok belirgin iç bükey ve iç bükey formlarda herhangi bir örnek olmadığı da belirlenmiştir (Çizelge 10).

Tabla açısı: Örneklerin büyük çoğunluğunun (50 adet) $180{ }^{0} \mathrm{C}^{\prime}$ lik açıyla sapa bağlandığı tespit edilmiștir. Ayrıca $0{ }^{0} \mathrm{Cve} 45{ }^{\circ} \mathrm{C}$ açılarının yanı sıra yağlıklarda ilave olarak $225{ }^{\circ} \mathrm{C}$ tabla açısına sahip bitkilerin bulunmadığı belirlenmiştir (Çizelge 10).

Tabla disk çiçeklerde antosiyanin varlığı: Örneklerde yaprakta olduğu gibi antosiyanin varlığ olmadığı gözlemlenmiştir.

Polen miktarı: Örneklerde ise örneklerin tamamında polen miktarı iyi olarak tespit edilmiştir.

Tane şekli: Örneklerin çoğunluğu ise geniş oval $(\% 56,8)$ formda iken dar oval $(\% 24,7)$ ve yuvarlak $(\% 16,0)$ formlarda örneklerin de yer aldığ 1 belirlenmiştir. Yağlık ayçiçeğinde öncelikli olmayan azda olsa uzun tane formuna $(\% 2,5)$ sahip örnekler olduğu da gözlemlenmiştir (Çizelge 10).

Tane rengi: Çoğunluk siyah renkte $(\% 86,5)$ olmak üzere açık kahverengi $(\% 7,4)$, kahverenginin $(\% 2,5)$ yanı sıra çok küçük oranlarda da olsa koyu kahverengi $(\% 1,2)$, kirli beyaz $(\% 1,2)$ ve beyaz renklerde $(\% 1,2)$ örneklerin olduğu da kaydedilmiştir (Çizelge 10).

Tohumda çizgililik durumu: Örneklerin tamamında gözlemlenen çizgiler ise büyük oranda hem kenarda hem de yanda $(\% 92,6)$ iken bazı örneklerde çizgilerin sadece yanda $(\% 4,9)$ ya da sadece kenarda $(\% 2,5)$ olduğu tespit edilmiştir (Çizelge 10).

Tohum kenarındaki çizgiler: $\mathrm{Bu}$ dağılım yağlık örneklerde \%74,1'i çok belirgin, \%13,6'sı belirgin ve \% 12,3' ü de yok ya da çok az belirgin olarak gözlenmiştir (Çizelge 10).

Tohum çizgilerin rengi: Örneklerde yine varyasyonun gözlemlendiği, dağılımın griden $(\% 82,7)$ açık kahverengiye $(\% 6,2)$, kirli beyazdan $(\% 9,9)$ beyaza $(\% 1,2)$ kadar değişen değerlerde olduğu belirlenmiştir (Çizelge 10). 
Çizelge 10. Yağlık ayçiçeği genetik kaynakları örneklerinde incelenen kalitatif karakterlere ait frekans tablosu.

Table 10. Frequency table of qualitative characters of oilseed sunflower sample of genetic resources.

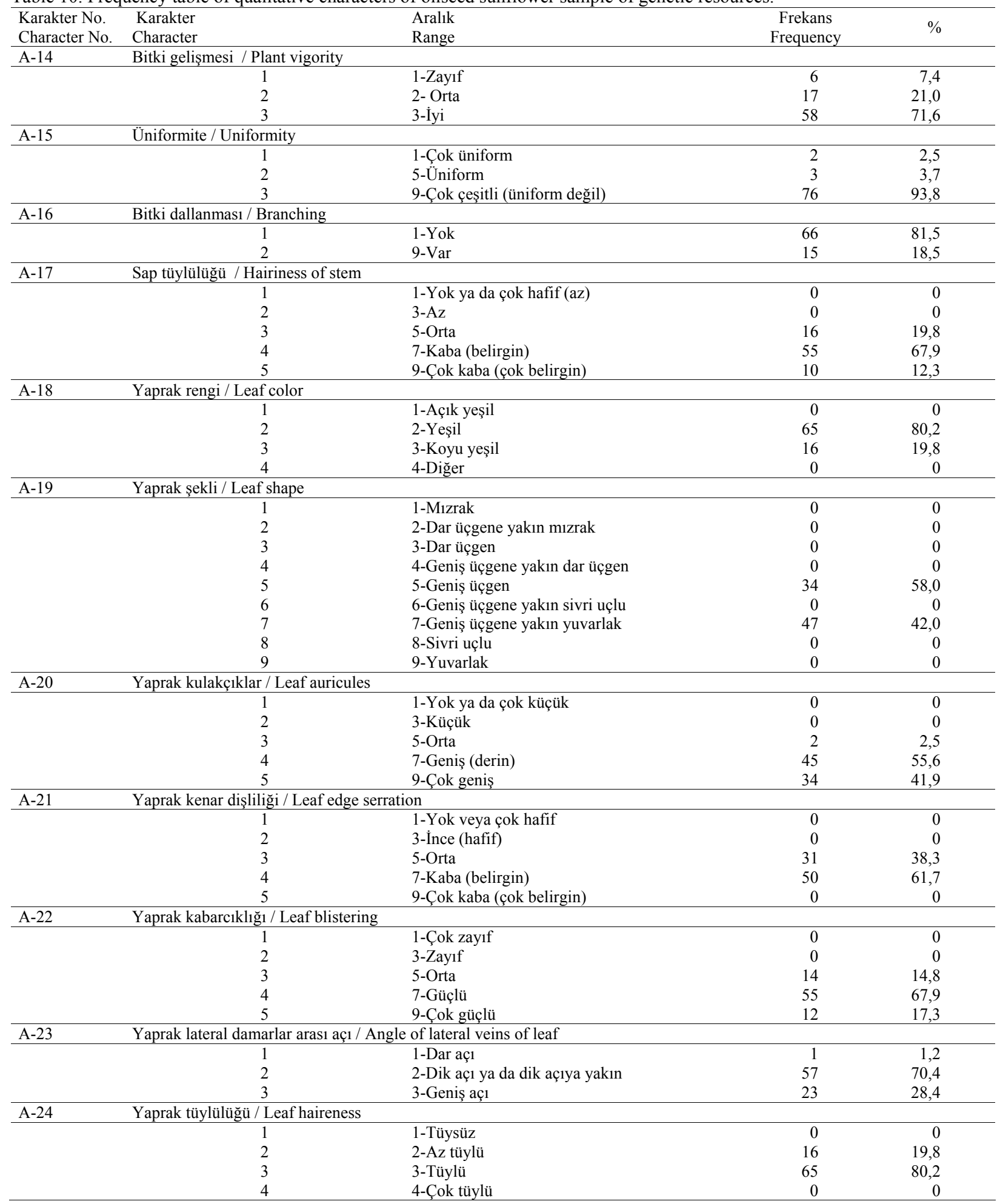


Çizelge 10. Devamı.

Table 10. Continued.

\begin{tabular}{|c|c|c|c|c|}
\hline $\begin{array}{l}\text { Karakter No. } \\
\text { Character No. }\end{array}$ & $\begin{array}{l}\text { Karakter } \\
\text { Character }\end{array}$ & $\begin{array}{l}\text { Aralık } \\
\text { Range }\end{array}$ & $\begin{array}{l}\text { Frekans } \\
\text { Frequency }\end{array}$ & $\%$ \\
\hline \multirow[t]{10}{*}{$\mathrm{A}-25$} & Tabla duruşu / Head inclination & & & \\
\hline & 1 & 1-Yatay & 0 & 0 \\
\hline & 2 & 2-Eğik & 0 & 0 \\
\hline & 3 & 3-Dik & 1 & 1,2 \\
\hline & 4 & 4-Dik gövde üzerinde yarım aşağı dönük & 9 & 11,1 \\
\hline & 5 & 5-Eğimli gövde üzerinde yarım aşağı dönük & 20 & 24,8 \\
\hline & 6 & 6-Gövde üzerinde tam aşağı dönük & 12 & 14,8 \\
\hline & 7 & $\begin{array}{l}\text { 7-Eğimli gövde üzerinde hafifçe aşağı } \\
\text { kıvrılmış }\end{array}$ & 38 & 46,9 \\
\hline & 8 & 8-Sapa doğru kuvvetlice aşağ 1 kıvrılmış & 1 & 1,2 \\
\hline & 9 & 9-Tümüyle içe doğru kıvrılmış & 0 & 0 \\
\hline \multirow[t]{7}{*}{ A-26 } & Tabla açısı / Head angle & & & \\
\hline & 1 & $1-0{ }^{0} \mathrm{C}$ & 0 & 0 \\
\hline & 2 & $2-45{ }^{0} \mathrm{C}$ & 0 & 0 \\
\hline & 3 & 3- $90{ }^{\circ} \mathrm{C}$ & 1 & 1,2 \\
\hline & 4 & 4- $135{ }^{\circ} \mathrm{C}$ & 30 & 37 \\
\hline & 5 & 5- $180{ }^{\circ} \mathrm{C}$ & 50 & 61,8 \\
\hline & 6 & 6- $225^{\circ} \mathrm{C}$ & 0 & 0 \\
\hline \multirow[t]{7}{*}{ A-27 } & Tabla şekli / Head shape & & & \\
\hline & 1 & 1-Çok belirgin iç bükey & 0 & 0 \\
\hline & 2 & 2- İç bükey & 0 & 0 \\
\hline & 3 & 3- Düz & 11 & 13,6 \\
\hline & 4 & 4- Diş bükey & 41 & 50,6 \\
\hline & 5 & 5- Çok belirgin dış bükey & 27 & 33,3 \\
\hline & 6 & 6-Şekilsiz & 2 & 2,5 \\
\hline \multirow[t]{11}{*}{ A-28 } & Tane rengi / Seed color & & & \\
\hline & 1 & 1-Beyaz & 1 & 1,2 \\
\hline & 2 & 2-Kirli beyaz & 1 & 1,2 \\
\hline & 3 & 3-Gri & 0 & 0 \\
\hline & 4 & 4-Açık kahverengi & 6 & 7,4 \\
\hline & 5 & 5-Kahverengi & 2 & 2,5 \\
\hline & 6 & 6-Koyu kahverengi & 1 & 1,2 \\
\hline & 7 & 7-Siyah & 70 & 86,5 \\
\hline & 8 & 8-Mor & 0 & 0 \\
\hline & 9 & 9-Açık gri & 0 & 0 \\
\hline & 10 & 10-Koyu gri & 0 & 0 \\
\hline \multirow[t]{5}{*}{ A-29 } & Tane şekli / Seed shape & & & \\
\hline & 1 & 1-Uzun & 2 & 2,5 \\
\hline & 2 & 2-Dar oval & 20 & 24,7 \\
\hline & 3 & 3-Geniş oval & 46 & 56,8 \\
\hline & 4 & 4-Yuvarlak & 13 & 16,0 \\
\hline \multirow[t]{5}{*}{$\mathrm{A}-30$} & Tohumda çizgililik durumu / $\mathrm{Pr}$ & f streaking at the edge of the seed & & \\
\hline & 1 & 1-Kenarda & 2 & 2,5 \\
\hline & 2 & 2-Yanda & 4 & 4,9 \\
\hline & 3 & 3-Hem kenarda hem de yanda & 75 & 92,6 \\
\hline & 4 & 4-Yok & 0 & 0 \\
\hline \multirow[t]{5}{*}{ A-31 } & Tohum kenarındaki çizgiler / S & at the edge of the seed & & \\
\hline & 1 & 1-Yok veya çok az belirgin & 10 & 12,3 \\
\hline & 2 & 2-Belirgin & 11 & 13,6 \\
\hline & 3 & 3-Çok belirgin & 60 & 74,1 \\
\hline & 4 & 4-Yok & 0 & 0 \\
\hline \multirow[t]{9}{*}{ A-32 } & Tohum çizgilerinin rengi / Colo & aking at the edge of the seed & & \\
\hline & 1 & 1-Beyaz & 1 & 1,2 \\
\hline & 2 & 2-Gri & 67 & 82,7 \\
\hline & 3 & 3-Kahverengi & 0 & 0 \\
\hline & 4 & 4-Siyah & 0 & 0 \\
\hline & 5 & 5-Sarı & 0 & 0 \\
\hline & 6 & 6-Açık kahverengi & 5 & 6,2 \\
\hline & 7 & 7-Kirli beyaz & 8 & 9,9 \\
\hline & 8 & 8 -Yok & 0 & 0 \\
\hline
\end{tabular}




\section{TARTIŞMA ve SONUÇ}

Çalışmanın kapsamında yer alan materyaller içerisinden yağlık ayçiçeği populasyonları değerlendirmeye tabi tutulmuş olup yapılan $\mathrm{ABA}$ sonucunda 12 PRIN oluşmuştur. 12 bileşene ait toplam varyans \%77,875 olarak belirlenmiştir. Yağlık populasyonlarda yapılan kapsamında belirtilen karakterler bakımından hem populasyonlar arasında hem de populasyonlar içerisinde önemli derecede varyasyonlar olduğu belirlenmiştir. Aynı şekilde 36 populasyon üzerinde 15 agromorfolojik karakterler ile karakterizasyon çalışmasını gerçekleştiren Kholgi ve ark. (2011) toplamda 4 ana bileşene ait varyansı \%78 olarak bildirmişlerdir. Elde edilen varyasyonun önemi Khoufi ve ark. (2013) ve Jockovic ve ark. (2012) tarafından da belirtilmiştir. Masvodza ve ark. (2015), çalışmaları sonucunda gözlemledikleri dar genetik yapı ile yüksek verimli çeşitlerin elde edilemeyeceğini ifade ederek genetik varyasyonun önemini vurgulamışlardır.

Çalışmada yer alan yağlık örneklerin tamamında geçerli olacak makineli hasata uygun çeşit geliştirilmesi noktasında bitki boyu önemli bir karakterdir. Yüksek verim açısından ise tablanın büyüklügünün yanı sıra tek bitki verimleri de dikkate alınması gereken bir karakter olarak ortaya çıkmaktadır.

Islah programlarının öncelikli hedefleri arasında yer alan verimi yükseltme hedefi tek bitki tartımları yüksek olan materyallerle önem arz etmektedir. Harlan ve De Wet (1971), intraspesifik (tür içi) düzeyde bitkilerin içerdikleri büyük varyasyon nedeniyle geleneksel siniflandirma uygulamalarının yapay olacağını belirterek, intraspesifik düzeyde formlardan söz etmenin daha uygun olacağını vurgulamışlardır. Yerel çeşitlerin geleneksel tarım şartlarında farklı formlarının bir arada yetiştiriliyor olmasından dolayı sürekli bir gen alışverişi olmakta, bunun sonucunda da örneklerde önemli derecelerde morfolojik varyasyon görülmektedir. Yerel çeşitler içindeki intraspesifik varyasyonda örneklerin dağ 1 lımında lokal coğrafik izolasyonların bulunmayışının etkisi olmaktadır. Benzer durum Tan ve ark. (2013a,b) tarafindan yapılan çalışmada görülen çeşitliliğin farklı ekolojilere sağlanan adaptasyonun yanı sıra çiftçinin yapmış olduğu seleksiyonunda rol oynadığı, benzerliklerin ise farklı bölgelerdeki çiftçiler arasındaki resmi olmayan tohum değişimlerinden kaynaklandığı sonuçlarına ulaşmışlardır. Çalışmada yer alan bitki, tabla, yaprak ve çiçeğe dair düşük oranlarda da olsa varyasyon gösteren diğer tüm karakterler mevcut yağlık ayçiçeği genetik kaynakları materyalinin tanımlanmasına, bilimsel araştırma veya islah amaçlarına uygun materyallerin kullanımı da bilim insanlarına yol göstereceğine inanılmaktadır.

Sonuç olarak; ekolojik koşullar ve tüketici isteklerine uygun çeşit geliştirme 1slah programlarının ana hedefleri arasında bulunmaktadır. Bu bağlamda, bu çalışma kapsamında değerlendirilen bu karakterlere göre yapılan tanımlamaların, ileride yapılacak ıslah çalışmalarında hedefe uygun materyal seçimi noktasında 1slahçılara büyük kolaylık sağlayacağı düşünülmektedir. Yine yağlık ayçiçeği örneklerinde piyasada kabul gören yüksek verimli, yüksek adaptasyon kabiliyetine sahip, ana ve 2. ürün koşullarına uygun, yüksek tane ve yağ verimine sahip çeşitlerin elde edilebilmesi sslah programlarında ebeveynlerin seçiminde zaman ve kaynak tasarrufu açısından büyük kolaylı sağlayacağı düşünülmektedir. $\mathrm{Bu}$ çalışma, belirtilen bu hedefler doğrultusunda değerlendirildiğinde sslah açısından çalışmanın başlangıcında hedeflenen sonuca ulaşıldığını göstermektedir.

Birçok araştırıcı tarafindan bitki genetik kaynaklarının değerlendirilmesi ve bunun dokümantasyonunun, mevcut koleksiyonlardaki genetik varyasyonun ortaya konması açısından önem taşıdığı belirtilmiştir (Bennet, 1970; Bunting ve Kuckuck, 1970). Mevcut genetik materyalin günümüzde ve gelecekte kullanılabilmesi için; kaybının önlenmesi ve korunmas1 gerekmektedir (Tan ve ark., 2013a, b; Tan ve ark., 2014). Bu amaçla, üretim/yenileme kapsamında çoğaltılan gen kaynağ 1 materyalinin uzun süreli olarak Türkiye Tohum Gen Bankasında muhafazaya alınması da çalışmadan elde edilen bir diğer sonuçtur.

\section{TEŞEKKÜR}

Bu çalışma, "Türkiye Yağlık ve Çerezlik Ayçiçeği (Helianthus annuus L.) Genetik Kaynaklarının Karakterizasyonu" isimli doktora tezinden 
hazırlanmıştır. Desteklerinden dolayı Ege Tarımsal Araştırma Enstitüsü Müdürlüğ̈̈ne ve TÜBİTAK

\section{LITERATÜR LISTESI}

Allard, R. W. 1970. Population structure and sampling methods. pp. 97-108. In: O. Frankel and E. Bennet (Eds.) Genetic Resources in Plants.

Andrade, A., P. Castillo, A. Vigliocco, S. Alemano, and G. Abdala. 2011. Sunflower responses to drought stress during early development. Chapter: 3, pp. 98-134. In: V.C. Hughes (Ed.) Sunflowers: Cultivation, Nutrition and Biodiesel Uses. Nova Science Publishers, Inc.,

Anonim. 2017. Türkiye İstatistik Kurumu (TÜİK). Ayçiçeğ verileri. http://www.tuik.gov.tr/PreTablo.do?alt id= 1001. Erişim tarihi: 19 Aralık 2017.

Anonymous. 1985. Sunflower Descriptors. International Board for Plant Genetic Resources (IBPGR). Rome, Italy.

Anonymous. 2000. UPOV Sunflower Descriptor List Guidelines for the conduct of tests for distinctness, üniformity and stability. TG/81/6. http://www. upov.int/test guidelines/en/list.jsp. Geneva, 2000. Son erişim tarihi: 24 Temmuz 2015

Anonymous. 2007. JMP ${ }^{\circledR}$ 7.0, Copyright (C) 2007, SAS Institute Inc., Cary, NC, USA.

Anonymous. 2017. FAOSTAT. http://www.fao.org/faostat /en/\#data/QC. Erișim tarihi: 19 Aralık 2017.

Arshad, M., M. K. Ilyas, and M. A. Khan. 2007. Genetic divergence and path coefficient analysis for seed yield traits in sunflower (Helianthus annuus L.) hybrids, Pakistan J. Bot. 39, 2009-2015.

Bedigan, D. 1981. Origin, diversity, exploration and collection of sesame. pp. 164-169. In: A. Ashri (Ed) Sesame: Status and Improvements Proc. of Expert Consultation. FAO Plant Production and Protection Paper No: 29. Food and Agriculture Organization of the United Nations. Rome, Italy.

Bennet, E. 1970. Tactics of plant exploration. pp. 157-180. In: O. Frankel and E. Bennet (Eds.) Genetic Resources in Plants.

Bunting, A. N., and H. Kuckuck. 1970. Ecological and agronomic studies related to plant exploration. pp. 181188. In: O. Frankel and E. Bennet (Eds.) Genetic Resources in Plants.

Clifford, H. T., and W. Stephenson. 1975. An introduction to Numerical Classification. Academic Press. New York.

Cantamutto, M., A. Presotto, I. F. Moroni, D. Alvarez, M. Poverene, and G. Seiler. 2010. High intra-specific diversity of wild sunflowers (Helianthus annuus L.) naturally developed in central Argentina. Flora 205: 306-312.
1003-2150092 numaralı projeye verilen destekten dolayı TÜBİTAK'a teşekkür ederiz.

Demir, İ. 1962. Türkiye'de Yetiștirilen Önemli Susam Çeşitlerinin Başlıca Morfolojik, Biyolojik ve Sitolojik Vasıfları Üzerinde Araştırmalar. Ege Üni. Zir. Fak. Yay. No: 53. Ege Üniv. Matbaas1.

Ghariani, S., N. Trifi-Farah, S. Marghali, M. Marrakchi, and M. Chakroun. 2003. Morphological characterization of Tunisian perennial ryegrass germplasm. Journal of Agriculture and Environment for International Development 97 (3-4): 197-205.

Granlund, M., and D. C. Zimmerman. 1975. Oil content of sunflower seeds as determined by wide-line nuclear magnetic resonance (NMR). Proc. N.D. Acad. Sci. 27: 128-133.

Harlan, J. R. 1951. Anotomy of gene centers. The American Naturalist 85: 97-103.

Harlan, J. R., and J. M. J. de Wet. 1971. Toward a rational classification of cultivated plants. Taxon 20: 509-517.

Heiser, C.B. Jr. 1978. Taxsonomy of Helianthus and origin of domesticated sunflower. pp. 31-53. In: J. F. Carter (Ed.) Sunflower Sci. and Technology. Agronomy 19.

Heiser, C.B. Jr. D. M. Smith, S. B. Clevenger, and W.C. Martin, Jr. 1969. The North American sunflowers (Helianthus annuus L.). Mem. Torrey Bot. Club 22 (3): $1-218$

Jockovic, M., R. Marinković, A. Marjanović, V. J. Radić, P. Čanak, and N. Hladni. 2012. Association between seed yield and some morphological characteristics in sunflower, Ratar, Povrt., 49: 53-57.

Karagoz, A., N. Zencirci, A. Tan, T. Taskın, H. Köksel, M. Surek, C. Toker, and K. Ozbek. 2010. Bitki genetik kaynaklarının korunması ve kullanımı (Conservation and utilization of plant genetic resources). Türkiye Ziraat Mühendisliği VII. Teknik Kongresi. 11-15 Ocak 2010. Ankara. Bildiriler Kitabi 1, s.155-177.

Kholghi, M., I. Bernousi, R. Darvishzadeh, A. Pirzad, and H. H. Maleki. 2011. Collection, evaluation and classification of Iranian confectionary sunflower (Helianthus annuus L.) populations using multivaraite statistical techniques. African Journal of Biotechnology 10 (28): 5444-5451.

Khoufi, S., K. Khalil A. T. S. da Jaime, A. Nadia, R. Salah, and B. T. Fayçal. 2013. Assessment of diversity of phenologically and morphologically related traits among adapted populations of sunflower (Helianthus annuus L.). Helia 36 (58): 29-40.

Masvodza, D. R., E. Gasura, N. Zifodya, P. Sibanda, and B. Chisikaurayi. 2015. Genetic diversity analysis of local and foreign sunflower germplasm (Helianthus annuus) for the national breeding program: Zimbabwe. Academic Journals, 6 (1): 1-7. 
Miller, J. F. 1987. Sunflower. Vol. 2. pp. 626-668. In: W Fehr (Ed.) Principle of Cultivar Development. Macmillan Pub. Co. NY.

Nooryazdan, H., H. Serieys, R. Baciliéri, J. David, and A. Bervillé. 2010. Structure of wild annual sunflower (Helianthus annuus L.) accessions based on agromorphological traits. Genetics Resources in Crop Evolution 57: 27-39.

Odong, T. L., J. Heerwaarden, T. J. L. van Hintum, F. A. Eeuwijk, and J. Jansen. 2013. Improving hierarchical KÜMEing of genotypic data via principal component analysis. Crop Science 53 (4): 1546-1554.

Putt, E. D. 1978. History and present word status. pp. 1-9. In: J. F. Carter (Ed.) Sunflower Science And Technology. American Society of Agronomy, Madison. Wl.

Roy, B. A., M. L. Stanton, and S. M. Eppley. 1999. Effects of environmental stress on leaf hair density and consequences for selection. Journal of Evolutionary Biology 12 (6): 1089-1103.

Schneiter, A. A., and J. F. Miller. 1981. Description of sunflower growth stages. Crop Sci. 21: 901-903.

Shamshad, M., S. K. Dhillon, V. Tyagi, and J. Akhatar. 2014. Assessment of genetic diversity in sunflower (Helianthus annuus L.) germplasm. International Journal of Agriculture and Food Science Technology 5 (4): 267-272. ISSN 2249-3050.

Sneath, P. H. A., and R. R. Sokal. 1973. Numerical Taxonomy. The Principles and Practice of Numerical Classification. Freeman, San Fransisco.

Steel, R. G. D., and J. H. Torrie. 1980. Principles and procedures of statistics. Mc Graw Hill Book Company Inc., New-York.

Tan, A. 1983. Sayısal Taksonomik Yöntemlerle Varyasyonun Saptanması. EBZAE, 30. Menemen.

Tan, A. 1992. Türkiye'de yayılış gösteren Beta L. (Chenopodiceae) türlerinin sinıflandırılması üzerine araştırmalar. Doktora Tezi. Ege Üni. Fen Bilimleri Ens. Bornova, İzmir.

Tan, A. 2009. Türkiye Geçit Bölgesi genetik çeşitliliğinin in situ (Çiftçi Şartlarında) muhafazası olanakları. Anadolu 19 (1): 1-12.

Tan, A. Ş. 2010. Sunflower (Helianthus annuus L.) researches in Aegean Region of Turkey." 8th European Sunflower Biotechnology Conference. SUNBIO 2010. 1-3 March 2010, Antalya, Turkey. Helia 33 (53): 77 84.
Tan, A. Ş. ve A. Tan. 1996. Türkiye susam (Sesamum indicum L.)' larının morfometrik varyasyon analizi. Anadolu. 6 (2): 1-23. Menemen. İzmir.

Tan, A. Ş., and A. Tan. 2010. Sunflower (Helianthus annuus L.) Landraces of Turkey, their collections conservation and morphmetric characterization. Helia 33 (53): 5562.

Tan, A. S., and A. Tan. 2011. Genetic resources of sunflower (Helianthus annuus L.) in Turkey. International Symposium on Sunflower Genetic Resources. October 16-20, 2011. Kusadasi, Izmir, Turkey. Helia 34 (55): $39-46$.

Tan, A. Ş., and A. Tan. 2012. Characterization of sunflower genetic resources of Turkey. 18th International Sunflower Conference, Argentina, Feb. 27 Marc-1 Feb., 2012.

Tan, A. S., M. Aldemir, A. Altunok, and A. Tan., 2013a. Characterization of confectionary sunflower (Helianthus annuus L.) genetic resources of Denizli and Erzurum provinces. Anadolu 23 (1): 5-11.

Tan, A. Ş., M. Aldemir, A. Altunok, and A. Tan. 2013b. Characterization of confectionary sunflower (Helianthus annuus L.) land races of Turkey. International Plant Breeding Congress. 10-14 November 2013, Antalya, Turkey.

Tan, A. Ş., A. Tan, M. Aldemir, A. Altunok, A. Peksüslü, A. İnal, H. Öztarhan, H. Kartal ve L. Aykas. 2014. Endüstri Bitkileri Genetik Kaynakları Projesi. 2014 Y1lı Gelişme Raporu. Ege Tar. Ara. Ens. Menemen. İzmir.

Upadhyaya, H. D., C. L. L. Gowda, and DVSSR Sastry. 2008. Plant genetic resources management: collection, characterization, conservation and utilization. Journal of SAT Agricultural Research 6: 1-15

Zeven, A. C., and J. M. J. de Wet. 1982 Dictionary of cultivated plants and their regions of diversity. Pudoc, Wageningen, the Netherlands.

Zukovsky, P. M. 1950. Cultivated plants and their wild relatives (Abstr. Transl. By. P.S. Hudson. 1962). Commonw. Agric. Bur. Fornham Royal, England.

Ward, Jr. J. H. 1963. Hierarchical Grouping to Optimize an Objective Function. Journal of the American Statistical Association 58: 236-244. 